The impact of international swap lines on stock returns of banks in emerging markets Alin Marius Andries, Andreas M. Fischer and Pinar Yeşin

SNB Working Papers $7 / 2015$ 


\section{Legal Issues}

\section{DISCLAIMER}

The views expressed in this paper are those of the author(s) and do not necessarily represent those of the Swiss National Bank. Working Papers describe research in progress. Their aim is to elicit comments and to further debate.

\section{COPYRIGHT@}

The Swiss National Bank (SNB) respects all third-party rights, in particular rights relating to works protected by copyright (information or data, wordings and depictions, to the extent that these are of an individual character).

SNB publications containing a reference to a copyright (C) Swiss National Bank/SNB, Zurich/year, or similar) may, under copyright law, only be used (reproduced, used via the internet, etc.) for non-commercial purposes and provided that the source is mentioned. Their use for commercial purposes is only permitted with the prior express consent of the SNB.

General information and data published without reference to a copyright may be used without mentioning the source. To the extent that the information and data clearly derive from outside sources, the users of such information and data are obliged to respect any existing copyrights and to obtain the right of use from the relevant outside source themselves.

\section{LIMITATION OF LIABILITY}

The SNB accepts no responsibility for any information it provides. Under no circumstances will it accept any liability for losses or damage which may result from the use of such information. This limitation of liability applies, in particular, to the topicality, accuracy, validity and availability of the information.

ISSN 1660-7716 (printed version)

ISSN 1660-7724 (online version)

(C) 2015 by Swiss National Bank, Börsenstrasse 15,

P.O. Box, $\mathrm{CH}-8022$ Zurich 


\title{
The impact of international swap lines on stock returns of banks in emerging markets
}

\author{
Alin Marius Andries ${ }^{1}$ \\ Andreas M. Fischer ${ }^{2}$ \\ Pınar Yeşin ${ }^{3}$
}

June 2015

\begin{abstract}
This paper investigates the impact of international swap lines on stock returns using data from banks in emerging markets. The analysis shows that swap lines by the Swiss National Bank (SNB) had a positive impact on bank stocks in Central and Eastern Europe. It then highlights the importance of individual bank characteristics in identifying the impact of swap lines on bank stocks. Bank-level evidence suggests that stock prices of local and less-well capitalized banks responded strongly to SNB swap lines. This new evidence is consistent with the view that swap lines not only enhanced market liquidity but also reduced risks associated with micro-prudential issues.
\end{abstract}

Keywords: Swap lines, foreign currency loans, bank stocks, emerging markets. JEL Classification Number: F15; F21; F32; F36; G15

1 Alexandru Ioan Cuza Uni. of Iasi, 22th Carol I Blvd, 700505, Iasi, Romania telephone $(+40740) 317921$

e-mail: alin.andries@uaic.ro

${ }^{2}$ Swiss National Bank and CEPR, Postfach, 8022 Zurich, Switzerland

telephone (+41 44) 6313294

e-mail: andreas.fischer@snb.ch

3 Swiss National Bank, Postfach, 8022 Zurich, Switzerland

telephone (+41 44) 6313969

e-mail: pinar.yesin@snb.ch

* We thank Steven Ongena, Martin Brown, Angelo Ranaldo, and an anonymous referee as well as seminar participants at the Swiss National Bank and the University of St. Gallen for helpful comments. The views expressed here are those of the authors and do not necessarily reflect the position of the Swiss National Bank. 


\section{Introduction}

In response to the global financial crisis, international swap lines between central banks of advanced economies and their counterparts in emerging market economies were introduced as a coordinated policy initiative. Empirical studies by Aizenman and Pasricha (2010), Moessner and Allen (2013), and Baba and Shim (2010) show supportive evidence that these international swap lines (hereafter, swap lines) were coincident with reductions in Covered Interest Parity (CIP) or Credit Default Swap (CDS) spreads. The country-level studies argue that swap lines prevented systemic risk and limited contagion during periods of market stress.

Although empirical studies have been able to identify macroprudential benefits arising from swap lines, a shortcoming of the literature is its narrow focus on country-level responses to swap lines. Country-level data do not shed light on the channels through which swap lines impact banks, i.e., the beneficiaries of the foreign liquidity provision. The country-level studies assume banks are homogenous. ${ }^{1}$ We know very little how banks with different characteristics respond to swap lines.

\footnotetext{
${ }^{1}$ For example, Goldberg et al. (2011) and Bruno and Shin (2014) acknowledge that European and Korean banks did not make equal use of liquidity provisions provided by swap lines.
} 
The objective of this paper is to determine the average daily impact of swap lines on stock returns using bank data from emerging markets. The identification strategy estimates the difference-in-difference of stock prices of Hungarian and Polish banks relative to other Central and Eastern European (CEE) countries conditioning on swap lines. In particular, we focus on Swiss National Bank (SNB) swap lines with the National Bank of Poland (NBP) and the Central Bank of Hungary $(\mathrm{MNB}){ }^{2}$ To identify the bank-specific response to swap lines, we examine the importance of bank characteristics. These characteristics include the level of foreign currency exposure, the funding structure, the ownership type, and the capital structure.

The empirical results are presented for two levels of aggregation. We first show the country-level finding that stock returns of banks increased with SNB swap lines. This empirical result is consistent with the view that swap lines with the SNB improved liquidity conditions in CEE between 2008 and 2010. In a second stage of the analysis, the importance of bank characteristics is examined. We show that the country-level approach masks a richer set of

\footnotetext{
${ }^{2}$ The experience in CEE before the financial crisis, particularly in Hungary and Poland, is overshadowed by the rapid growth of residential mortgage loans denominated in Swiss francs. The problem of currency mismatches became acute after the Swiss franc appreciated strongly during the financial crisis and many CEE banks were excluded from the interbank market for Swiss francs.
} 
bank-level findings.

The paper makes three contributions to the literature on unconventional measures and their impact on banks. ${ }^{3}$ To our knowledge this is the first study to examine the impact of swap lines on banks. The new evidence on liquidity provision in emerging markets shows that stock prices of domestic and less-well capitalized banks respond strongly to SNB swap lines. ${ }^{4}$

A second contribution is to show that the success of swap lines is not dependent on currency choice. Swap lines are normally defined for exchange rates between the home currency and a major reserve currency (i.e., in U.S. dollar, euro, or yen). This, however, was not the case for swap lines between the SNB and CEE central banks. These swap line agreements were between the euro and the Swiss franc.

A third contribution shows that gains from swap lines beyond national jurisdictions were limited. Only Hungarian and Polish banks benefited from swap lines between the SNB and the NBP and between the SNB and the MNB. The transmission of liquidity provision through swap lines does not

\footnotetext{
${ }^{3}$ Our paper is closest in spirit to Chodorow-Reich (2014) and Alfaro et al. (2014). The study by Chodorow-Reich (2014) investigates the impact of FOMC announcements on stock prices of financial firms. Similarly, the paper by Alfaro et al. (2014) examines the impact of Brazilian capital controls on stock prices of Brazilian firms.

${ }^{4}$ For the literature on swap lines and emerging markets see, Aizenman and Pasricha (2010), Baba and Shim (2010), and Bruno and Shin (2014).
} 
follow the same cross border channels as liquidity shocks generated by other unconventional measures (i.e., quantitative easing). ${ }^{5}$

The paper is organized as follows. Section 2 reviews the motivation for SNB swap lines with the MNB and the NBP. Section 3 presents the empirical methodology. Section 4 discusses the data. Section 5 presents the empirical results. Section 6 concludes.

\section{SNB swap lines and CEE banks}

Swiss franc and other foreign currency loans to the non-banking sector were extremely popular in CEE before the financial crisis. ${ }^{6}$ Households and small firms increasingly borrowed in a lower-yielding foreign currency to finance their mortgages or business investments. The shaded columns in Figure 1 show the share of foreign currency loans as a percentage of total loans to the non-banking sector in select CEE countries for 2009:Q1. ${ }^{7}$ Figure 1 shows that at the height of the financial crisis, the majority of the outstanding

\footnotetext{
${ }^{5}$ For example, studies by Fratzscher et al. (2013) and Bauer and Neely (2014) show that liquidity shocks arising from asset purchases in advanced countries have spillover effects for emerging market economies.

${ }^{6}$ Auer and Kraenzlin (2011), Beer et al. (2010), and Yesin (2013) discuss in detail Swiss franc lending in CEE. Brown and de Haas (2012), Brown et al. (2011), and Brown et al. (2014) study the determinants of FX lending in CEE.

${ }^{7}$ The date 2009:Q1 is the first available observation from the CHF Lending Monitor, an ongoing project of the Swiss National Bank with the aim to understand the scope of Swiss franc lending in Europe.
} 
loans to the non-banking sector in several CEE countries was denominated in foreign currency. The same figure also illustrates that Swiss franc loans were particularly popular in Hungary, Poland, Croatia, Serbia, and Romania. In the remaining countries, euro loans probably comprised the vast share of foreign currency loans.

As the financial crisis escalated so did the funding tensions in Swiss francs for many CEE banks. The interbank market for Swiss francs, which funded a large share of the CEE bank activities, was impaired. Further, most CEE banks lacked access to a Swiss franc-denominated deposit base or the domestic operations of the SNB (the SNB accepts non-domestic banks as counterparties). This situation of market stress reduced credit lines for Swiss francs to CEE.

In this context, the SNB entered into temporary swap line agreements with several central banks between 2008 and 2010. Their objective was to improve the liquidity conditions for the Swiss franc in international financial markets. Table 1 lists the major swap line agreements involving the SNB. The most relevant SNB swap line agreements for this study are shaded grey in Table 1. These agreements were with the European Central Bank (ECB), the NBP, and the MNB. 
The first agreement between the SNB and the ECB was a weekly swap line beginning on October 20, 2008. This swap line was euros for Swiss francs with no pre-specified limit. The objective was to provide Swiss franc funding to banks in the euro area jurisdiction.

A second swap line agreement between the SNB and the NBP began on November 17, 2008. The NBP joined the weekly EUR/CHF swap auctions between the SNB and the ECB. Under this agreement, the SNB provided the NBP with Swiss francs against euros, while the NBP provided Swiss francs to its counterparties and received Polish zloties.

A third swap line agreement between the SNB and MNB began on February 2, 2009. The terms and conditions were similar to the previous agreements with the ECB and the $\mathrm{NBP}^{8}$ On January 18, 2010, it was communicated that the last EUR/CHF swap operation with the ECB, the NBP, and the MNB would be on January 25, 2010.

Figure 2 shows swap volumes between the euro and the Swiss franc for the three SNB swap agreements with the ECB, the MNP, and the NBP.

\footnotetext{
${ }^{8} \mathrm{An}$ open issue is whether the SNB swaps were supported by ECB cooperation agreements with the NBP and MNB. These central bank cooperations were collateralized transactions that allowed the NBP and MNB to obtain euros. ECB (2014), which reviews the history of ECB swap line agreements with other central banks during financial crisis, does not mention this.
} 
Positive values reflect borrowing of Swiss francs by foreign central banks. The aggregate position is shown because the SNB did not publish separately volumes for the three central banks. ${ }^{9}$ The figure shows a growing demand for Swiss francs with a peak volume of 40 billion CHF in May 2009. Thereafter, the volume drifts towards zero before the end of 2009 .

A further swap line agreement designed to extend Swiss franc liquidity was the temporary reciprocal currency arrangements between the Federal Reserve (Fed), the ECB, the Bank of England (BoE), the Bank of Japan (BoJ), and the SNB. These agreements were announced on April 6, 2009 and were terminated on February 1, 2010. Although this swap line was not actively used, it will be considered in the empirical analysis.

\section{The empirical setup}

The analysis of the stock price response of CEE banks to SNB swap lines is conducted at two levels of aggregation. The first level begins with the country-level regressions used by Aizenman and Pasricha (2010) and Bruno and Shin (2014) to study the impact of Federal Reserve swaps on interest rates in emerging markets. The regression is used to test the hypothesis that swap lines improve liquidity conditions and this improvement is reflected in

\footnotetext{
${ }^{9} \mathrm{CHF}$ volume figures are not published by the ECB, the NBP, and the MNB.
} 
higher stock prices for banks in countries with swap lines:

$$
\begin{array}{r}
\Delta p_{i j t}=\beta_{1} S W A P_{j t}^{S N B \mid X}+\beta_{2} D A T E_{t}^{S N B \mid X}+\Sigma_{1=k}^{K} \alpha_{k} \Delta p_{i j t-k} \\
+ \text { other }_{t}+\nu_{j}+\mu_{t}+\epsilon_{i j t},
\end{array}
$$

where $\Delta p_{i j t}$ denotes the daily change in the $l n$ share price of CEE bank $i$ in country $j$ at time $t$. The dummy variable, $S W A P_{j t}^{S N B \mid X}$, is the interaction term $D A T E_{t}^{S N B \mid X} * C O U N T R Y_{j}^{S N B \mid X}$ used in Aizenman and Pasricha (2010) and Bruno and Shin (2014) and is +1 for the period and country when the swap lines with central bank $X$ in country $j$ are active and 0 otherwise. The dummy variable, $D A T E_{t}^{S N B \mid X}$, is +1 for the period when the swap lines with central bank $X$ in country $j$ are active and 0 otherwise. The country dummy variable, $C O U N T R Y_{j}^{S N B \mid X}$, is +1 for country $j$ in which the SNB had a swap line with central bank $X$ and 0 otherwise. This dummy variable is not included separately because the regression includes country fixed effects. The variable, other, , captures (macroeconomic) control variables. These controls include the VIX uncertainty variable in $t$, the change in the ln EUR/CHF exchange rate in $t$, and the change in the $l n$ stock market index for European banks in $t$. The regression equation also includes lagged dependent variables, fixed (country $j$ ), and time (quarterly $t$ ) effects. The residual is denoted by $\epsilon_{i j t}$. 
The SNB was involved in five separate swap line agreements, therefore their impact on stock prices of CEE banks is estimated separately. The following swap line dummies are considered: SNB-ECB swap line, $S W A P_{j t}^{S N B \mid E C B}$; SNB-NBP swap line, $S W A P_{j t}^{S N B \mid N B P}$; SNB-MNB swap line, $S W A P_{j t}^{S N B \mid M N B}$; joint dummy NBP and MNB, $S W A P_{j t}^{S N B \mid C E E}$; the multilateral swap line between the Fed, the BoJ, the ECB, the BoE, and the SNB in USD, $S W A P_{j t}^{S N B \mid M U L T 1}$; and the multilateral swap line between the SNB, the ECB, the Fed, and the BoE in reciprocal currencies, $S W A P_{j t}^{S N B \mid M U L T 2}$. The time periods of the swap line agreements are listed in Table 1.

Our variable of interest is $S W A P_{j t}^{S N B \mid X}$ with the prior $\beta_{1}>0$ in equation (1). In other words, stock prices of CEE banks respond positively to liquidity access through swap lines. Because central banks were concerned about stigma effects and published only aggregate swap volumes at best, the market was unable to determine which banks made use of swap lines. This forces us to define periods of swap line agreements with a dummy. This practice has been used in Aizenman and Pasricha (2010), Moessner and Allen (2013), and others. Thus in our analysis in section 5, a response effect of bank stock prices on SNB swap lines cannot be interpreted as evidence that banks made use of the Swiss franc liquidity. Rather the bank's stock price increased on 
the information that it had access to liquidity provisions. Hence, the timing of the swap dummies needs to be interpreted as defining periods of liquidity access when financial markets were under stress and not as a volume effect. ${ }^{10}$ Aizenman and Pasricha (2010), Moessner and Allen (2013), Baba and Shim (2010), Bruno and Shin (2014) and others show that CDS or interest rate spreads fell in country with swap lines. The key assumption is that financial markets responded uniformly to swap lines. Our objective is to relax this equality assumption and to allow for structural features of CEE banks. Below four propositions that condition on bank characteristics are discussed in terms of their stock price responses to swap lines.

Proposition \# 1: Banks with high levels of foreign currency loans benefit more from swap lines than do banks with low levels of foreign currency loans.

The assumption is that banks with (long-term) foreign denominated assets are unable to refinance their (short-term) foreign currency liabilities during periods of financial market stress. Because many financial markets for foreign currency (i.e., Libor, national interbank market) were impaired during the financial crisis, swap lines served the function of liquidity provi-

\footnotetext{
${ }^{10} \mathrm{We}$ also considered the signalling effect associated with the swap line announcement dates. Regressions with initial swap line dates show that this interpretation of the announcement effect, as opposed to our interpretation of access to CHF liquidity over a distinct period, is not robust. These results are discussed in the empirical section.
} 
sion. Therefore, we expect stock prices of banks with high levels of foreign currency loans to respond positively to liquidity access through swap lines.

Proposition \# 2: Banks with a higher dependence on short-term funding are more reliant on swap lines.

This proposition says that a bank's funding structure matters when markets are impaired. Under proposition 2, stock prices of banks with a high reliance on the interbank market are expected to respond positively to swap lines.

Proposition \# 3: Foreign owned banks are less reliant on swap lines than are domestic banks.

The proposition says that the response of bank stocks depends on bank ownership and their interconnectedness with foreign parent banks. This proposition is also consistent with Bruno and Shin (2014). The proposition highlights the view that foreign owned banks enjoy access to secure foreign currency lines through their parent bank. However, domestic banks are liquidity constrained when local interbank markets are impaired. This means stock prices of domestically owned banks should respond more strongly to swap lines than stocks of foreign owned banks.

Proposition \# 4: Banks with a weak capital structure are reliant on swap lines. 
Swap lines act as a lifeline in that they allow (distressed) banks that suffer from counterparty risk time to find new (foreign denominated) liquidity. Banks with a higher capital base should be less reliant on swap lines. In this case, the swap line takes on a financial stability function in that they are providing liquidity to less-well capitalized banks.

To test these four propositions at the bank level, the baseline specification defined by equation (1) is extended to include information for bank $i$. The bank-level regression equation takes the following form:

$$
\begin{array}{r}
\Delta p_{i j t}=\beta_{1} S W A P_{j t}^{S N B \mid X}+\beta_{2} B A N K_{i j t}^{\text {char }}+\beta_{3} B A N K_{i j t}^{\text {char }} * S W A P_{j t}^{S N B \mid X} \\
+ \text { other }_{t}+\nu_{j}+\mu_{t}+\epsilon_{i j t},
\end{array}
$$

where for space constraints the lags and $D A T E_{t}^{S N B \mid X}$ from equation (1) are not shown. The variable, $B A N K_{i j t}^{\text {char }}$, captures bank specific information: information on the bank's foreign currency exposure, funding structure, ownership type, and capital structure. Our test is the interaction term between the swap line dummy and bank specific information, $S W A P_{j t}^{S N B \mid X} * B A N K_{i j t}^{\text {char }}$. If the interaction term is significant and positive, then this statistical evidence is consistent with the view that individual banks with particular characteristics benefitted from swap lines more than the country average. Such evidence also suggests that banks did not respond uniformly to liquidity provision. 


\section{Data}

The dataset comprises balance sheet information for 47 commercial banks operating in 15 CEE countries from January 3, 2005 to December 31, 2012. ${ }^{11}$ The data set is constructed in the following manner. BankScope collects data on 462 commercial banks from CEE in 2012. Of the 462 banks, only 92 of them are publicly traded and have detailed information for at least 5 years. Next, hand-collected information on FX risk for each bank for each year from the bank's annual reports and financial statements is available for 47 banks. Of these 47 banks, 18 are local (domestically owned) banks and 29 are foreign-owned banks. ${ }^{12}$ Appendix 1 lists the banks in our sample.

We group bank characteristics into four categories: the level of foreign currency exposure, the funding structure, the ownership type (i.e., foreign or domestic control), and the capital structure. Four measures of foreign

\footnotetext{
${ }^{11}$ The countries are Bosnia and Herzegovina, Bulgaria, Croatia, Czech Republic, Hungary, Latvia, Lithuania, Macedonia, Montenegro, Poland, Romania, Serbia, Slovakia, Slovenia, and Ukraine.

${ }^{12}$ As in Claessens and van Horen (2014), we classify banks into foreign and local banks depending on whether $50 \%$ or more of the bank's stocks are owned by foreigners or by central, local governments or domestic private actors. Across CEE countries, foreign ownership in the banking sector has grown dramatically in the recent decade, and by 2008 , foreign banks controlled around $80 \%$ of the assets in the regions banking industry. Western banks such as Raiffeisen Bank International, Erste Bank, UniCredit, Intesa, KBC, or regional banks such as OTP and NLB, are a dominant force in CEE (EIB, 2013). In our sample, 18 banks are subsidiaries of an International Banking Group with a large exposure to a region (at least 5 subsidiaries in CEE region).
} 
currency exposure are used to test proposition 1: the share of assets in CHF measured as the ratio of assets in CHF to total assets; the share of assets in foreign currencies measured as the ratio of total assets in foreign currencies to total assets; the net position in CHF measured as the ratio of assets in CHF minus liabilities in CHF to total assets; and the net position in foreign currencies measured as the ratio of total assets in foreign currencies minus total liabilities in foreign currencies to total assets.

The second bank characteristic is the bank's funding structure used to test proposition 2. Following Demirguc-Kunt and Huizinga (2010), Ivashina and Scharfstein (2010), Altunbas et al. (2011) and Beltratti and Stulz (2012), we define funding fragility as the ratio between the sum of deposits from other banks, other deposits, and short term borrowing over total deposits plus money market and short-term funding.

The third bank characteristic is foreign ownership and international connectedness used to test proposition 3. Foreign ownership is defined as a dummy variable to be +1 if $50 \%$ or more of banks stocks are foreign owned (Claessens and van Horen, 2014), otherwise 0. International connectedness is defined by membership in a banking group. It is a dummy variable +1 if the bank is a subsidiary of an international banking group with at least 5 
subsidiaries in the CEE region, otherwise 0. This dummy measures the role of international connectedness without an explicit structure for ownership type.

The fourth bank characteristic is the capital structure of banks used to test proposition 4. As in Demirguc-Kunt et al. (2013), two measures of capital structure are used. The first variable is $C A P 1_{i j t}$, which is the total capital ratio (the risk-adjusted regulatory capital ratio) calculated according to Basel rules as the sum of Tier 1 and Tier 2 capital divided by risk-adjusted assets and off-balance sheet exposures. The second variable is $C A P 2_{i j t}$, which is defined as Tier 1 Ratio calculated as Tier 1 divided by risk-adjusted assets and off-balance sheet exposures. ${ }^{13}$

To isolate the impact of swap lines on stock returns of CEE banks, three control variables are considered. The first variable is the VIX index of implied volatility in S\&P500 index options. The VIX index reflects aggregate financial market volatility, as well as the price of market volatility, see Adrian and Shin (2010). Higher market uncertainty should be negatively correlated with the return in bank stocks. The second control variable is the one-day return of the EUR/CHF exchange rate. A depreciation in the Swiss franc

\footnotetext{
${ }^{13}$ Tier 1 capital comprises shareholder funds and perpetual, noncumulative preference shares.
} 
should help support stock prices. The third control variable is the STOXX Europe 600 banks index return. The coefficient of this variable is expected to be positively correlated with the return of share prices for individual banks. Appendix 2 reports definitions and sources of all variables and Appendix 3 Panel B reports descriptive statistics of variables used in our analysis.

\section{Empirical Results}

This section presents empirical results on the stock price response of CEE banks to SNB swap lines. The results for two levels of aggregation are presented. The first subsection documents country-level responses to swap lines. The second subsection records bank-level responses to swap lines.

The sample is from January 1, 2005 to December 31, 2012. All regressions include the VIX uncertainty variable, the change in the $\ln$ EUR/CHF exchange rate, the change in the $\ln$ European-wide banking stock index, and three lags of the dependent variable as controls. In addition, country and time effects are included in all regressions. The standard errors in all regressions control for country cluster effects.

The estimated coefficients of the control variables are consistent with their priors. The coefficient of the VIX variable is negative and highly significant. 
In other words, bank stock prices increase with lower uncertainty. Similarly, the coefficient of the change in the $\ln$ EUR/CHF exchange rate is positive and significant. This is also consistent with the prior that a weaker Swiss franc is coincident with an increase in bank stock prices that are exposed to currency risk. The coefficient of the change in the $\ln$ European bank index is positive and significant in all regressions. This result says that there is strong co-movement between stock prices of European and CEE banks.

\subsection{Country-level responses to SNB swap lines}

The country-level responses to SNB swap lines yield three empirical findings. First, stock prices of Hungarian and Polish banks responded positively to SNB swap lines with the NBP and the MNB. This finding extends the country-level results of Bruno and Shin (2014) and others using CDS and interest rate spreads for a new asset class, namely stock prices. Second, the swap line between the SNB and the ECB had no impact for CEE banks in the euro area. This result suggest that other countries in the euro area, i.e., Austria and Italy, had possibly a larger demand for Swiss francs than the CEE countries in the euro area, i.e., Slovenia and Slovakia. Third, multilateral swap lines between the SNB and major central banks had no impact on stock prices of CEE banks. In other words, CEE banks only benefitted from 
swap lines if their country's central bank had a swap line agreement with the SNB. This result suggests that CEE financial markets were highly segmented during periods of market stress and gains from swap lines beyond national jurisdictions were limited.

Table 2 presents regressions for equation 1 with four different dummy variables proxying different swap line agreements. Column 1 shows the (joint) swap dummy for Hungary and Poland, $S W A P_{j t}^{S N B \mid C E E}$, that captures periods when the SNB-NBP and/or the SNB-MNB swap lines were active in the two countries. The coefficient of the swap line agreements is 0.2155 and is statistically significant. This coefficient says that stock prices of Hungarian and Polish banks increased daily on average $0.22 \%$ more than the CEE average during the period when the swap lines were active. This is equivalent to an accumulated return of $5.5 \%$ over the period of the swap line. For completeness, we include the time dummy of the swap line, $D A T E_{j t}^{S N B \mid C E E}$. The positive coefficient of the time dummy suggests that stock markets in CEE benefited from the introduction of SNB swap lines with the NBP and the MNB.

The dummy proxying the SNB-ECB swap line, $S W A P_{j t}^{S N B \mid E C B}$, is shown in column 2 of Table 2. The coefficient of the dummy is negative and statis- 
tically insignificant. The negative coefficient says that stock returns of CEE banks in the ECB jurisdiction (i.e., Slovenia and Slovakia) did not increase on account of the liquidity access in Swiss francs. This result is possibly explained by the fact that CEE countries in the euro area have relatively small volumes of Swiss franc denominated loans compared to Hungary and Poland. As in column 1, the time dummy for the ECB swap line, $D A T E_{j t}^{S N B \mid E C B}$, is positive and statistically significant.

Columns 3 and 4 test the Hungarian and Polish swap lines separately. The regressions show that both dummy variables are positive and statistically significant. The coefficients are 0.29 for Hungary and 0.18 for Poland. In both regressions the country and date variables are significant. The time dummy variables for both swap lines are positive and statistically significant.

Next, results from robustness tests of the joint dummy for SNB-MNB and SNB-NBP swap lines, $S W A P_{j t}^{S N B \mid C E E}$, are shown in Table 3. The coefficient of the variable of interest, $S W A P_{j t}^{S N B \mid C E E}$, is stable and significant for different sample periods. For comparative purposes, Column 1 presents the regression from the previous table for the full sample period from 2005 to 2012. Column 2 shows there is no change in the coefficient of $S W A P_{j t}^{S N B \mid C E E}$ after the Lehman shock. Similarly, the regression for the shortened sample 
that covers the Lehman shock to the Euro crisis in May 2010 shows that the coefficient for $S W A P_{j t}^{S N B \mid C E E}$ remains stable. The fourth sample starts March 1, 2009 (i.e., at least one month after the SNB swap lines were introduced with CEE central banks). In this regression, $S W A P_{j t}^{S N B \mid C E E}$ remains statistically significant, however the date dummy is no longer statistically significant. This latter result suggests that potential spillovers from swap lines outside national jurisdictions were only temporary at best. The positive and statistically significant results from the time dummy shown in Table 2 may be attributed to an announcement effect across CEE stock markets.

Table 4 considers whether a signalling (announcement) effect is captured in $S W A P_{j t}^{S N B \mid C E E}$. The regressions in Table 4 include an announcement dummy that corresponds to the time period between the announcement of the swap line agreements and the time when they were first effective. Because of space constraints, the regressions in Table 4 do not show coefficients of the controls (i.e., lags and the three control variables).

The regressions in Table 4 do not support evidence of a signalling channel. The signal dummy for the CEE swaps and the ECB swap dummies have a coefficient value of 0.3 and 0.12 , however they are statistically insignificant. Individually, the signalling effect for the MNB and NBP are 
also positive but it is only significant for the MNB. It is important to note that $S W A P_{j t}^{S N B \mid C E E}, S W A P_{j t}^{S N B \mid N B P}$, and $S W A P_{j t}^{S N B \mid M N B}$ remain significant even in the presence of announcement effects. The regressions show that Hungarian and Polish banks benefitted from swap line access with the SNB over the full period and this swap line effect cannot be attributed to a one-time announcement effect. Although the empirical results suggest that Hungarian banks responded more strongly to swap lines than Polish banks, this result needs to be interpreted with caution. The number of Hungarian banks ( 2 banks) in our sample is considerably smaller than the number of Polish banks (10 banks). Because of this difference in the number of banks, it is our preference to work with $S W A P_{j t}^{S N B \mid C E E}$ rather than the individual country dummies for the SNB-MNB and SNB-NBP swap lines.

Next, we test the robustness of $S W A P_{j t}^{S N B \mid C E E}$ against other SNB swap lines with major central banks. Table 5 shows regressions with $S W A P_{j t}^{S N B \mid C E E}$ along with $S W A P_{j t}^{S N B \mid E C B}$ in EUR/CHF, $S W A P_{j t}^{S N B \mid M U L T 1}$ in USD/CHF, and $S W A P_{j t}^{S N B \mid M U L T 2}$ in various currencies. The regressions show that $S W A P_{j t}^{S N B \mid C E E}$ remains positive and significant, whereas the coefficients of the two multilateral swap lines are much smaller and in two cases negative. Further, the statistical significance is not established. We interpret these 
country-level results as follows: only the Hungarian and Polish banks benefited from the direct access to the swap lines.

In the next subsection, the specification in column 1 in Table 2 without $D A T E_{t}^{S N B \mid C E E}$ is treated as the baseline. The exclusion of the time dummy, $D A T E_{t}^{S N B \mid C E E}$, is motivated by the non robustness result in Table 3 . To test the four propositions outlined in section 3, bank specific information together with its interaction with the swap dummy is added to the baseline specification.

\subsection{Bank-level responses to SNB swap lines}

This subsection presents evidence on the stock price response of Hungarian and Polish banks controlling for bank specific characteristics. The findings show that bank characteristics are important for understanding the the stock price response to swap lines. The bank characteristics are motivated by the four propositions discussed in section 3. They include information on the bank's foreign currency exposure, funding structure, ownership type, and capital structure. Surprisingly, the evidence on the response effect conditional on banks' currency exposure is found to be weak. Instead, the empirical findings show that funding structure, ownership type, and capital 
structure are statistically significant, suggesting that the response of bank stocks to swap lines is dependent on bank characteristics.

Table 6 presents regressions that test proposition 1's conjecture: higher currency exposure should result in a higher stock price response. The regression in column 1 records information on the bank's share of CHF assets to total assets, whereas column 2 considers foreign assets to total assets. Columns 3 and 4 consider their respective net positions. The results in three out of four cases show that stock prices of CEE banks with a high foreign currency exposure responded negatively to swap lines. The four measures capturing foreign currency exposure are however never statistically significant at acceptable critical levels.

Next, the interaction terms between foreign currency exposure and $S W A P_{j t}^{S N B \mid C E E}$ are considered. There is only limited evidence at best that supports the view that the stock price response is strongest for banks with the largest currency exposure. Only the regression presented in column 2 yields the expected result. The coefficient of the interaction term with total foreign currency assets to total assets is 0.16 and statistically significant. This says that the stock price of Hungarian and Polish banks with a high foreign currency exposure in their asset position responded positively to swap lines. Because of the 
mixed results for different measures of currency exposure, we interpret the evidence in Table 6 as being weakly consistent (at best) with proposition 1. A possible explanation is that banks with high foreign currency exposure were either well hedged or other bank characteristics mattered.

Table 7 presents information on the stock price response to information on a bank's funding structure. Funding structure is proxied by funding fragility. Proposition 2 says that the stock price of banks relying on short-term funding will respond positively to a swap line agreement. Funding fragility has a coefficient of -0.157 that is highly significant. This says that if a bank's funding structure is short term, the bank's stock price falls. However, the coefficient's sign reverses for Hungarian and Polish banks that have access to swap lines. The interaction of swap lines and funding fragility has a coefficient of 0.288 and is statistically significant. From this evidence, we conclude that the funding structure is an important factor in explaining the stock price response to swap lines.

Table 8 presents regressions that test the importance of ownership structure. The evidence is consistent with proposition 3. The proposition says that foreign-owned banks have access to foreign exchange through the parent bank, however domestic banks do not enjoy this form of liquidity insurance 
when interbank markets are impaired. The prior is the stock price of local banks should respond positively to swap lines. To test this, column 1 in Table 8 presents a regression which introduces a foreign ownership dummy $(+1$ when more than $50 \%$ is foreign owned) and the interaction term to the baseline specification. The coefficient of the foreign ownership dummy is 0.032 . This says that the return on stock prices of foreign owned CEE banks was on average higher than local CEE banks. This term however is statistically insignificant. Next, the coefficient of the foreign ownership dummy interacted with the swap dummy is -0.104 and is statistically significant at the $10 \%$ level. This result says that stock prices of local banks in Hungary and Poland increased more than the average Hungarian and Polish bank during the period of the swap line.

An alternative measure of international connectedness, defined as member of a banking group, is considered in column 2 of Table 8. The dummy, banking group, is +1 when a bank is part of a banking group with subsidiaries in at least five countries in the CEE region. Note, this form of organizational structure does not imply foreign ownership and therefore possible access to foreign exchange through the parent bank. The results for bank group show that the coefficient of the dummy is 0.013 and statistically 
insignificant. However, the coefficient of the interaction term is 0.023 and statistically significant at the $10 \%$ level. This result highlights the importance of ownership as opposed to connectedness, because the stock price of banks active in international banking groups benefitted from liquidity access through swap lines.

Table 9 presents evidence consistent with proposition 4 that says swap lines supported CEE banks with a weak capital structure. In other words, the stock price of banks with a less sound capital structure responded strongly to swap lines. To see this, column 1 in Table 9 presents a regression that adds the total capital ratio of banks $(C A P 1)$ and their interaction term $\left(S W A P_{j t}^{S N B \mid C E E} * C A P 1\right)$ to the baseline regression. The coefficient for $C A P 1$ is close to zero and statistically insignificant, yet the coefficient of the interaction term is -0.024 and is statistically significant. This result says that the stock price of Hungarian and Polish banks with a higher capital ratio did not increase as much as those with a low capital ratio. Next, the regression with Tier 1 capital $(C A P 2)$ is presented in column 2. Again, the coefficient of the capital structure term, $C A P 2$, is nearly zero and statistically insignificant. However, the interaction term, $S W A P_{j t}^{S N B \mid C E E} * C A P 2$ is 0.015 and statistically significant. From this evidence, we conclude that the 
stock price of less-well capitalized banks in Hungary and Poland responded more strongly to the timing of a swap line agreement than did the stock price of banks with a more sound capital structure. This result suggests, whether intended or not, swap lines also had a financial stability dimension.

\section{Conclusions}

The strong response of CEE bank stocks to swap lines suggests that this unconventional form of liquidity provision impacted a broader range of financial assets (i.e., interest rate spreads, CDS rates, or exchange rates) than has been previously examined. The analysis for bank stocks reconfirms findings in previous studies that gains from swap lines outside national jurisdictions were limited. This empirical finding reenforces the desire of emerging market economies to sign international swap lines with central banks of major currencies.

The analysis of bank stocks also allow us to go one level deeper and to determine whether swap lines triggered asymmetric response effects at the bank level. The literature has until now assumed that financial assets respond uniformly to swap lines. The bank-level analysis suggests that the effectiveness of international swap lines is also partially dependent on the structure 
of a country's banking system. Stock prices of local and less-well capitalized banks responded the strongest to swap line agreements. This new evidence is consistent with the view that swap lines were not only important in providing liquidity but also took on functions associated with micro-prudential concerns. 


\section{References}

Adrian, T., Shin, H.S., 2010. Liquidity and leverage, Journal of Financial Intermediation 19, 418-437.

Aizenman, J., Pasricha, G. K., 2010. Selective swap arrangements and the global financial crisis: Analysis and interpretation, International Review of Economics and Finance 19, 353-365.

Alfaro, L., Chari, A., Kanczuk, F., 2014. The real effects of capital controls: Credit constraints, exporters and firm investment, mimeo.

Altunbas, Y., Manganelli, S., Marqus-Ibanez, D., 2011. Bank risk during the financial crisis: Do business models matter? European Central Bank Working Paper, No. 1394.

Auer, R. A., Kraenzlin, S., Liebeg, D., 2012. How do Austrian banks fund their Swiss franc exposure?, OENB Financial Stability Report 24 (December), 54-61.

Auer R. A., Kraenzlin, S., 2011. International liquidity provision during the financial crisis: A view from Switzerland, Federal Reserve Bank of St. Louis Review 93(6), 409-418.

Baba, N., Shim, I., 2010. Policy responses to dislocations in the FX swap market: The experience of Korea, BIS Quarterly Review (June), 29-39.

Bauer, M. D., Neely, M., 2014. International channels of the Feds unconventional monetary policy, Journal of International Money and Finance 44, $24-46$.

Beer, C., Ongena, S., Peter, M., 2010. Borrowing in foreign currency: Austrian households as carry traders, Journal of Banking and Finance 34(9), $2198-2211$.

Beltratti, A., Stulz, R.M., 2012. The credit crisis around the globe: Why did some banks perform better, Journal of Financial Economics 105, 1-17.

Brown, M., De Haas, R., 2012. Foreign banks and foreign currency lending in emerging Europe, Economic Policy 27(69), 57-98.

Brown, M., Ongena, S. Yesin, P., 2014. Information asymmetry and foreign 
currency borrowing by small firms, Comparative Economic Studies 56(1), 110-131.

Brown, M., Ongena, S., Yesin, P., 2011. Foreign currency borrowing by small firms in the transition economies, Journal of Financial Intermediation 20(3), 285-302.

Bruno, V., Shin, H. S., 2014. Assessing macroprudential policies: Case of South Korea, Scandinavian Journal of Economics 116(1), 128-157.

Chodorow-Reich, G., 2014. Effects of unconventional monetary policy on financial institutions, mimeo.

Claessens, S., van Horen, N., 2014. Foreign banks: Trends and impact, Journal of Money, Credit and Banking, 46(1), 295-326.

Demirguc-Kunt, A., Huizinga, H., 2010. Bank activity and funding strategies: The impact on risk and return. Journal of Financial Economics 98, 626-650.

Demirguc-Kunt, A., Detragiache, E., Merrouche, O., 2013. Bank Capital: Lessons from the Financial Crisis, Journal of Money, Credit and Banking $45,1147-1164$.

European Central Bank, 2014. Experience with foreign currency liquidityproviding central bank swaps, Monthly Bulletin (August), 65-82.

European Investment Bank, 2013. Banking in Central and Eastern Europe and Turkey - Challenges and Opportunities, http : //vienna initiative.com/wp-content/uploads/2013/02/Banking-in-Centraland-Eastern-Europe-and-Turkey-Challenges-and-Opportunities.pdf.

Eichengreen, B., Hausmann, R., 1999. Exchange rates and financial fragility. NBER Working Paper 7418. Cambridge, MA.

Fratzscher, M., Lo Duca, M., Straub, R., 2013. On the international spillovers of US quantitative easing, Working Paper Series 1557, European Central Bank.

Goldberg, L. S., Kennedy, C., Miu, J., 2011. Central bank dollar swap lines and overseas dollar funding costs, FRBNY Economic Policy Review (May), 3-20. 
Ivashina, V., Scharfstein, D., 2010. Bank lending during the financial crisis of 2008, Journal of Financial Economics 97, 319338.

Moessner, R., Allen, W. A., 2013. Central bank swap line effectiveness during the euro area sovereign debt crisis, Journal of International Money and Finance 35, 167-178.

Obstfeld, M., Shambaugh, J. C., Taylor, A. M., 2009. Financial instability, reserves, and central bank swap lines in the panic of 2008, American Economic Review 99(2), 480-486.

Ongena, S., Popov, A., Udell, G., 2013. "When the cats away the mice will play": Does regulation at home affect bank risk-taking abroad? Journal of Financial Economics 18, 727-750.

Yesin, P., 2013. Foreign currency loans and systemic risk in Europe, Federal Reserve Bank of St Louis Review 95(3), 219-236. 
Figure 1: Share of foreign currency loans as a percentage of total loans in the non banking sector in Eastern Europe as of 2009:Q1.

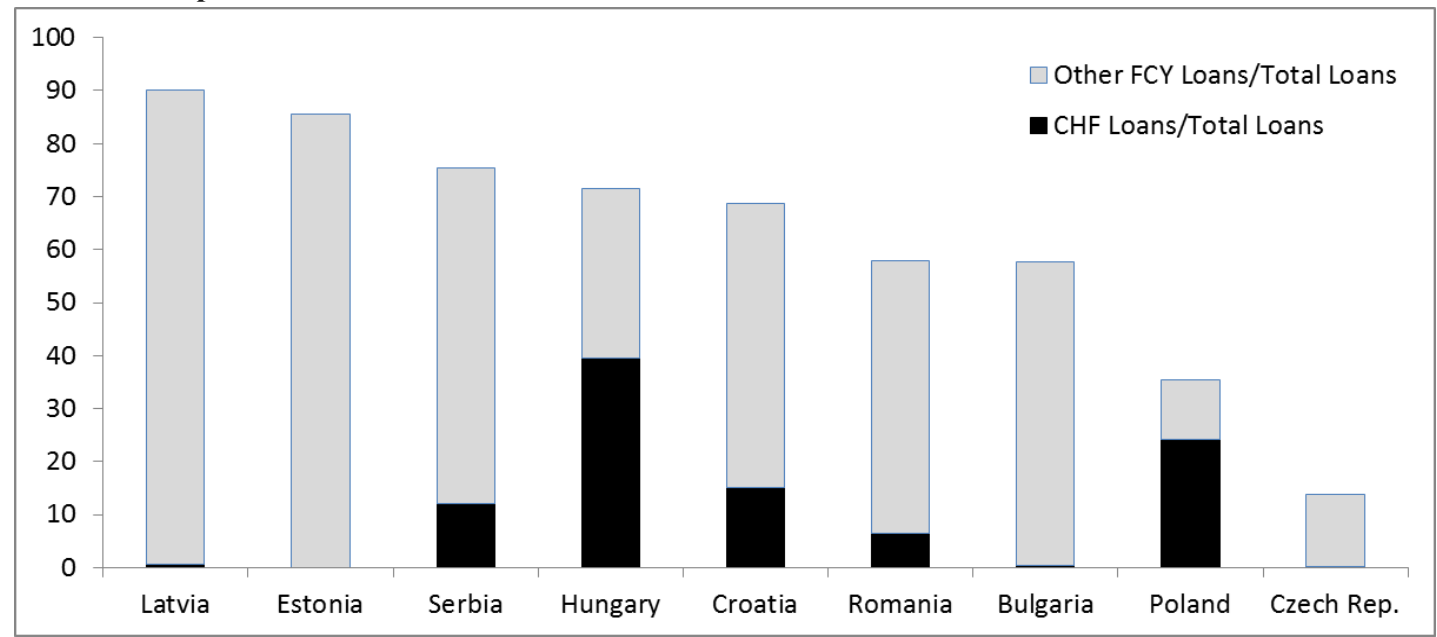

Note: CHF, Swiss francs; FCY, foreign currency. 
Figure 2: Balances from EUR/CHF Swap Operations

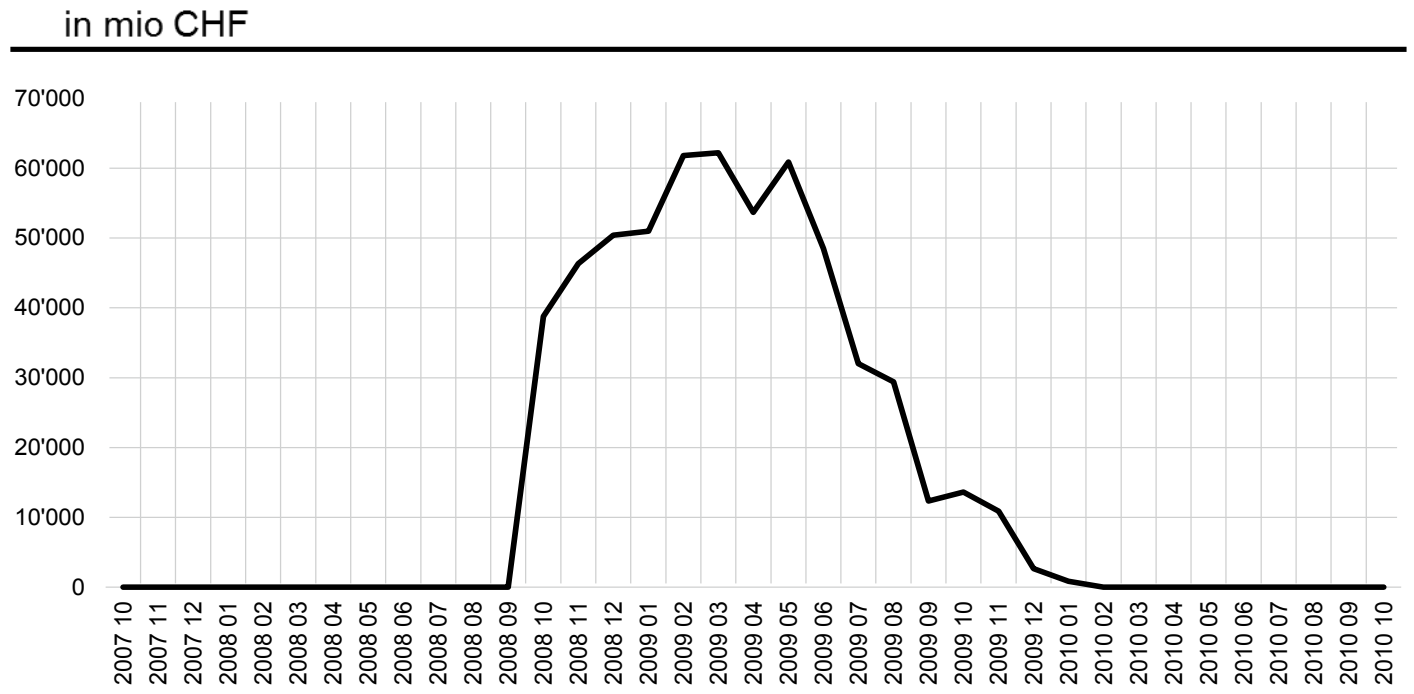

Source: SNB 


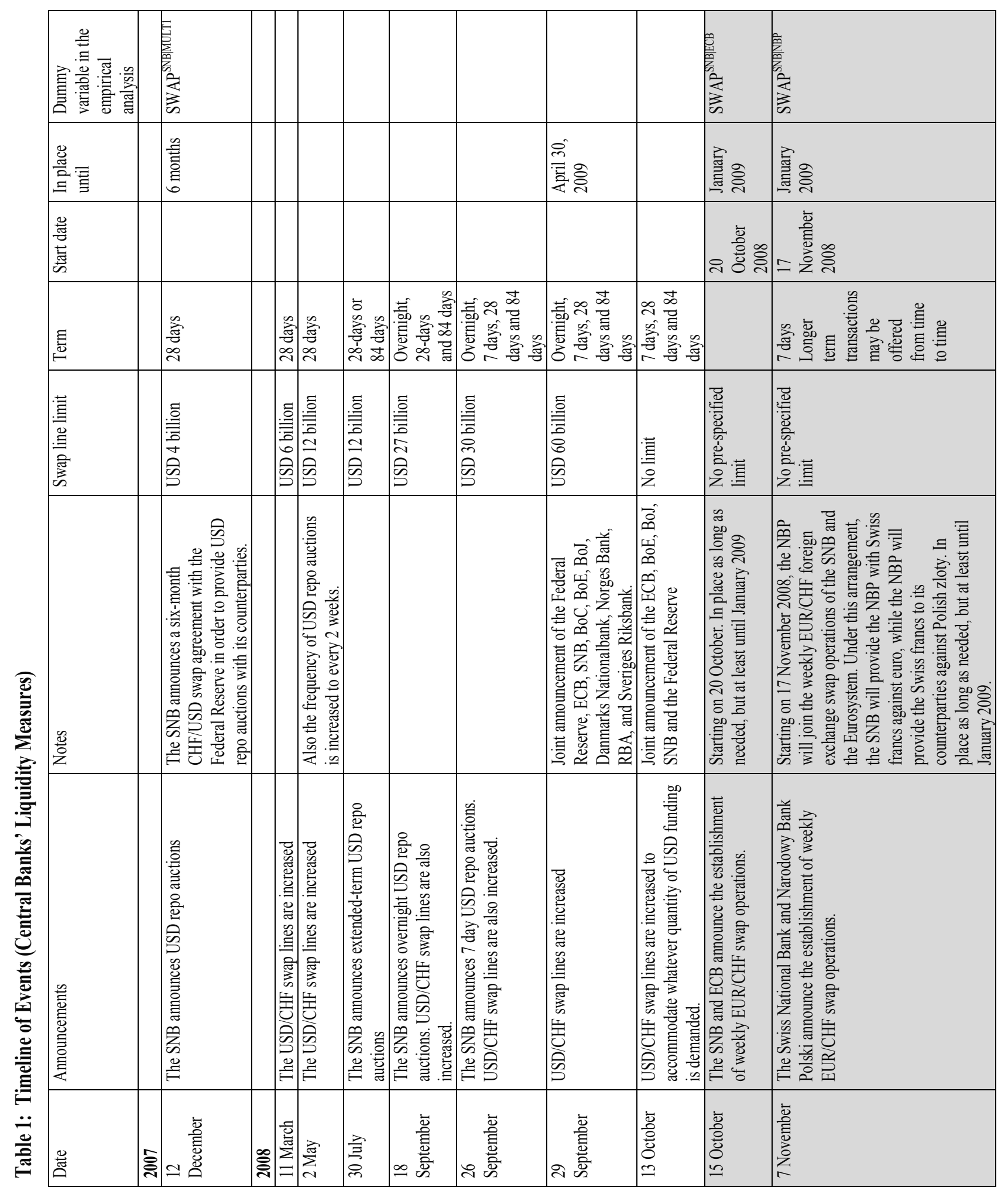




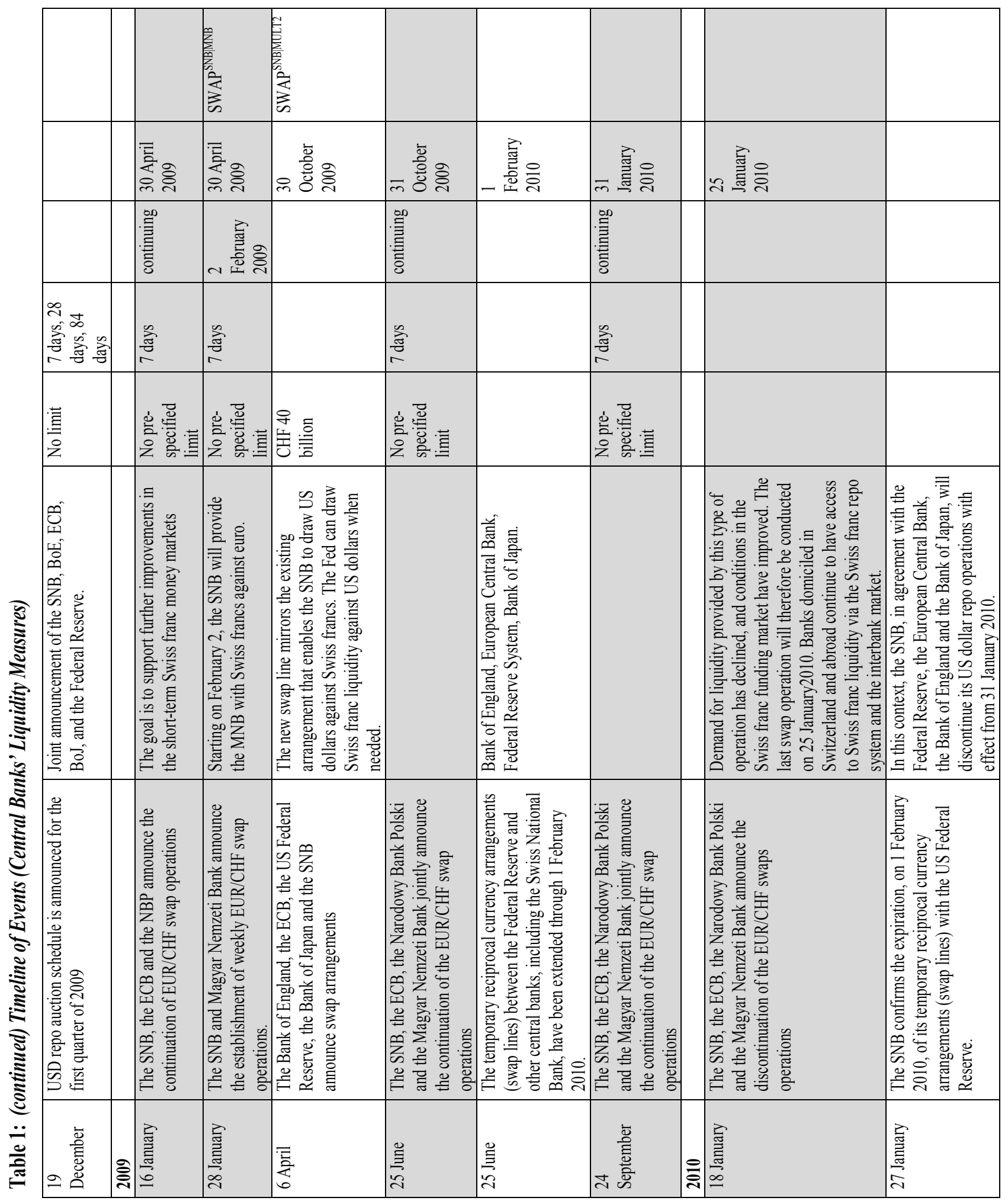

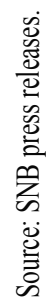


Table 2: Estimating impact of the SNB swap on Hungarian and Polish banks

This table reports the results of regressions that examine the impact of the SNB swap on Hungarian and Polish banks. We estimate alternative versions of the following regression specification:

$$
\Delta \mathrm{p}_{\mathrm{i}, \mathrm{j}, \mathrm{t}}=\beta_{1} \times S W A P_{j t}^{S N B \mid X}+\beta_{2} \times S w a p D a t e_{t}^{S N B \mid X}+\phi_{k} \times \Delta \mathrm{p}_{\mathrm{i}, \mathrm{j}, \mathrm{t}-\mathrm{k}}+\alpha \times \text { Other }_{\mathrm{t}}+v_{j}+\mu_{t}+\varepsilon_{\mathrm{i}, \mathrm{j}, \mathrm{t}}
$$

where $\Delta \mathrm{p}_{\mathrm{i}, \mathrm{j}, \mathrm{t}}$ denotes the bank performance measured as the change in the ln share price of a CEE bank $\mathrm{i}$ in country $\mathrm{j}$ at time t; the variable, $S W A P_{j t}^{S N B \mid X}=S$ wapDate $_{t}^{S N B \mid X} \times S$ wapCountry ${ }_{j}^{S N B \mid X}$, is +1 for the period and country when the swap lines with country or group $X$ are active and 0 otherwise and denotes one of the alternative dummy swap lines: SNB-CEE $\left(S W A P_{j t}^{S N B \mid C E E}\right)$ - is a dummy variable taking a one if the bank operates in Hungary for period 2 February 2009 - 25 January 2010 or in Poland for period 17 November 2008-25 January 2010 , SNB-ECB swap line $\left(S W A P_{j t}^{S N B \mid E C B}\right)-$ is a dummy variable taking a one if the bank operates in any country member of Euro zone for period 20 October 2008-25 January 2010, SNB-MNB swap line $\left(S W A P_{j t}^{S N B \mid M N B}\right)$ - is a dummy variable taking a one if the bank operates in Hungary for period 2 February 2009 25 January 2010, and SNB-NBP swap line $\left(S W A P_{j t}^{S N B \mid N B P}\right)$ is a dummy variable taking a one if the bank operates in Poland for period 17 November 2008-25 January 2010; the dummy variable, SwapDate $t^{S N B \mid X}$, is +1 for the

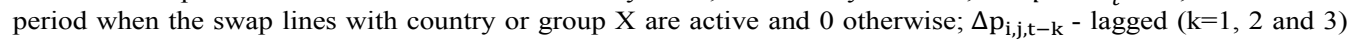
values of dependent variable; the Other $_{\mathrm{t}}$ captures (macroeconomic) control variables and include $V I X-$ to control for investor sentiment and market volatility; Exchange rate (CHF/EUR) return - to control for movements on $\mathrm{FX}$ markets; European banking systems performance (STOXX® Europe 600 Banks index return) - to control for European banking system overall performance. We include country fixed effects $v_{j}$ and time (quarter) fixed effects $\mu_{t}$ in all specifications to control for omitted variables. Standard errors are reported in brackets and account for clustering at the country level. We use $* * *, * *$, and $*$ to denote statistical significance at the $1 \%, 5 \%$, and $10 \%$ levels, respectively.

\begin{tabular}{|c|c|c|c|c|}
\hline $\begin{array}{l}\text { Dependent: Bank } \\
\text { performance }\end{array}$ & Model 1 & Model 2 & Model 3 & Model 4 \\
\hline SNB-CEE & $\begin{array}{r}0.2155^{* * * *} \\
(0.0436)\end{array}$ & & & \\
\hline CEE - Date & $\begin{array}{r}0.2794 * * * \\
(0.0924)\end{array}$ & & & \\
\hline SNB-ECB & & $\begin{array}{l}-0.0414 \\
(0.0502)\end{array}$ & & \\
\hline ECB - Date & & $\begin{array}{r}0.4892 * * * \\
(0.1523)\end{array}$ & & \\
\hline SNB-MNB & & & $\begin{array}{r}0.2899^{* * *} \\
(0.0623)\end{array}$ & \\
\hline MNB - Date & & & $\begin{array}{r}0.2864 * * * \\
(0.0976)\end{array}$ & \\
\hline & & & & $\begin{array}{r}0.1761^{* * *} \\
(0.0354)\end{array}$ \\
\hline NBP - Date & & & & $\begin{array}{r}0.2929 * * * \\
(0.0952)\end{array}$ \\
\hline $\begin{array}{l}\text { Bank performance } \\
\text { (Lag 1) }\end{array}$ & $\begin{array}{r}-7.3347^{* *} \\
(3.1066)\end{array}$ & $\begin{array}{r}-7.3264^{* *} \\
(3.1086)\end{array}$ & $\begin{array}{r}-7.2932^{* *} \\
(3.1118)\end{array}$ & $\begin{array}{r}-7.3237^{* *} \\
(3.1078)\end{array}$ \\
\hline $\begin{array}{l}\text { Bank performance } \\
\text { (Lag 2) }\end{array}$ & $\begin{array}{r}-3.1197 * * * \\
(0.8593)\end{array}$ & $\begin{array}{r}-3.1109^{* * *} \\
(0.8602)\end{array}$ & $\begin{array}{r}-3.0819^{* * *} \\
(0.8608)\end{array}$ & $\begin{array}{r}-3.1089^{* * *} \\
(0.8581)\end{array}$ \\
\hline $\begin{array}{l}\text { Bank performance } \\
\text { (Lag 3) }\end{array}$ & $\begin{array}{r}-1.4538^{*} \\
(0.8420)\end{array}$ & $\begin{array}{r}-1.4459^{*} \\
(0.8383)\end{array}$ & $\begin{array}{r}-1.4305^{*} \\
(0.8376)\end{array}$ & $\begin{array}{r}-1.4438^{*} \\
(0.8401)\end{array}$ \\
\hline VIX & $\begin{array}{r}-0.0242^{* * *} \\
(0.0054)\end{array}$ & $\begin{array}{r}-0.0251^{* * *} \\
(0.0055)\end{array}$ & $\begin{array}{r}-0.0247^{* * *} \\
(0.0055)\end{array}$ & $\begin{array}{r}-0.0241^{\text {**** }} \\
(0.0054)\end{array}$ \\
\hline $\begin{array}{l}\text { Exchange rate } \\
\text { (CHF/EUR) return }\end{array}$ & $\begin{array}{r}18.8622 * * * \\
(3.3138)\end{array}$ & $\begin{array}{r}18.7436^{* * *} \\
(3.2947)\end{array}$ & $\begin{array}{r}18.9286^{* * *} \\
(3.3183)\end{array}$ & $\begin{array}{r}18.8630 * * * \\
(3.3137)\end{array}$ \\
\hline $\begin{array}{l}\text { European banking } \\
\text { systems performance }\end{array}$ & $\begin{array}{r}17.0030 * * * \\
(5.9493) \\
\end{array}$ & $\begin{array}{r}16.9765 * * * \\
(5.9441) \\
\end{array}$ & $\begin{array}{r}17.0080^{* * * *} \\
(5.9511)\end{array}$ & $\begin{array}{r}17.0028 * * * \\
(5.9493) \\
\end{array}$ \\
\hline Country FE & YES & YES & YES & YES \\
\hline Time (Quarter) FE & YES & YES & YES & YES \\
\hline R-squared & 0.048 & 0.048 & 0.048 & 0.048 \\
\hline N. of cases & 71888 & 71888 & 71888 & 71888 \\
\hline $\begin{array}{l}\text { Mean of dependent } \\
\text { variable }\end{array}$ & -0.0421 & -0.0421 & -0.0421 & -0.0421 \\
\hline
\end{tabular}


Table 3 Robustness checks with different sample periods (Hungary and Poland together)

This table reports the results of regressions that examine the impact of the SNB swap on Hungarian and Polish banks using different sample periods. We estimate alternative versions of the following regression specification:

$$
\Delta \mathrm{p}_{\mathrm{i}, \mathrm{j}, \mathrm{t}}=\beta_{1} \times S W A P_{j t}^{S N B \mid X}+\beta_{2} \times \text { SwapDate }_{t}^{S N B \mid X}+\beta_{3} \times S \text { WapCountry }{ }_{j}^{S N B \mid X}+\phi_{k} \times \Delta \mathrm{p}_{\mathrm{i}, \mathrm{j}, \mathrm{t}-\mathrm{k}}+\alpha \times \text { Other }_{\mathrm{t}}+v_{j}+\mu_{t}+\varepsilon_{\mathrm{i}, \mathrm{j}, \mathrm{t}}
$$

where $\Delta \mathrm{p}_{\mathrm{i}, \mathrm{j}, \mathrm{t}}$ denotes the bank performance measured as the change in the $\ln$ share price of a CEE bank $\mathrm{i}$ in country $\mathrm{j}$ at time $\mathrm{t}$; the variable, $S W A P_{j t}^{S N B \mid X}=S w a p D a t e_{t}^{S N B \mid X} \times S$ wapCountry ${ }_{j}^{S N B \mid X}$, is +1 if the bank operates in Hungary for period 2 February 2009-25 January 2010 or in Poland for period 17 November 2008-25 January 2010; the dummy variable, $S$ wapDate ${ }_{t}^{S N B \mid X}$, is +1 for the period when the swap lines with Hungary (2 February 2009-25 January 2010) or Poland (17 November 2008-25 January 2010) are active and 0 otherwise; $\Delta \mathrm{p}_{\mathrm{i}, \mathrm{j}, \mathrm{t}-\mathrm{k}}$ - lagged $(\mathrm{k}=1,2$ and 3$)$ values of dependent variable; the $O$ ther $_{\mathrm{t}}$ captures (macroeconomic) control variables and include $V I X$ - to control for investor sentiment and market volatility; Exchange rate (CHF/EUR) return - to control for movements on FX markets; European banking systems performance (STOXX® Europe 600 Banks index return) - to control for European banking system overall performance. In Model 2 we report estimates for the period after 15 September 2008 - Lehman Brothers files for bankruptcy. In Model 3 we report estimates for the period after 15 September 2008 - Lehman Brothers files for bankruptcy until 23 April 2010 Greece officially requests financial support from the euro area countries and the IMF. We include country fixed effects $v_{j}$ and time (quarter) fixed effects $\mu_{t}$ in all specifications to control for omitted variables; and $\varepsilon_{\mathrm{i}, \mathrm{j}, \mathrm{t}}$ is the error term. Standard errors are reported in brackets and account for clustering at the country level. We use $* * *$, $* *$, and $*$ to denote statistical significance at the $1 \%, 5 \%$, and $10 \%$ levels, respectively.

\begin{tabular}{|c|c|c|c|c|}
\hline $\begin{array}{l}\text { Dependent: Bank } \\
\text { performance }\end{array}$ & $\begin{array}{c}\text { Model } 1 \\
\text { Full sample }\end{array}$ & $\begin{array}{c}\text { Model } 2 \\
\text { After } 15 \text { sep } \\
2008\end{array}$ & $\begin{array}{c}\text { Model } 3 \\
\text { Between } 15 \\
\text { sep } 2008 \text { and } \\
23 \text { apr } 2010\end{array}$ & $\begin{array}{c}\text { Model } 4 \\
30 \text { days after } \\
\text { the } \\
\text { Swap dates }\end{array}$ \\
\hline SNB-CEE & $\begin{array}{r}0.2155^{* * * *} \\
(0.0436)\end{array}$ & $\begin{array}{r}0.2141 * * * \\
(0.0428)\end{array}$ & $\begin{array}{r}0.2023^{* * *} \\
(0.0419)\end{array}$ & $\begin{array}{r}0.3658^{* *} \\
(0.1657)\end{array}$ \\
\hline CEE - Date & $\begin{array}{r}0.2794 * * * \\
(0.0924)\end{array}$ & $\begin{array}{r}0.2861 * * * \\
(0.0935)\end{array}$ & $\begin{array}{r}0.2548 * * * \\
(0.0832)\end{array}$ & $\begin{array}{r}0.1550 \\
(0.1956)\end{array}$ \\
\hline $\begin{array}{l}\text { Bank performance } \\
\text { (Lag 1) }\end{array}$ & $\begin{array}{r}-7.3347^{* *} \\
(3.1066)\end{array}$ & $\begin{array}{r}-6.6935^{* *} \\
(3.2284)\end{array}$ & $\begin{array}{l}-2.2938 \\
(3.9771)\end{array}$ & $\begin{array}{r}-7.2020^{*} \\
(4.2119)\end{array}$ \\
\hline $\begin{array}{l}\text { Bank performance } \\
\text { (Lag 2) }\end{array}$ & $\begin{array}{r}-3.1197 * * * \\
(0.8593)\end{array}$ & $\begin{array}{r}-2.9420 * * * \\
(0.7971)\end{array}$ & $\begin{array}{r}-1.4487 \\
(0.9704)\end{array}$ & $\begin{array}{r}-3.7327 * * * \\
(1.3091)\end{array}$ \\
\hline $\begin{array}{l}\text { Bank performance } \\
\text { (Lag 3) }\end{array}$ & $\begin{array}{r}-1.4538^{*} \\
(0.8420)\end{array}$ & $\begin{array}{r}-1.5531 \\
(1.0022)\end{array}$ & $\begin{array}{r}-0.5963 \\
(1.2913)\end{array}$ & $\begin{array}{r}-0.9215 \\
(0.8244)\end{array}$ \\
\hline VIX & $\begin{array}{r}-0.0242^{* * *} \\
(0.0054)\end{array}$ & $\begin{array}{r}-0.0205^{* * *} \\
(0.0052)\end{array}$ & $\begin{array}{r}-0.0165^{* *} \\
(0.0084)\end{array}$ & $\begin{array}{r}-0.0279^{* * *} \\
(0.0087)\end{array}$ \\
\hline $\begin{array}{l}\text { Exchange rate } \\
\text { (CHF/EUR) return }\end{array}$ & $\begin{array}{r}18.8622 * * * \\
(3.3138)\end{array}$ & $\begin{array}{r}15.4017 * * * \\
(2.3985)\end{array}$ & $\begin{array}{r}37.9272 * * * \\
(10.3117)\end{array}$ & $\begin{array}{r}0.5723 * * * \\
(0.1548)\end{array}$ \\
\hline $\begin{array}{l}\text { European banking } \\
\text { systems } \\
\text { performance }\end{array}$ & $\begin{array}{r}17.0030 * * * \\
(5.9493)\end{array}$ & $\begin{array}{r}16.6209^{* * *} \\
(5.7324)\end{array}$ & $\begin{array}{r}18.3878 * * * \\
(6.1878)\end{array}$ & $\begin{array}{r}0.1894 * * * \\
(0.0625)\end{array}$ \\
\hline $\begin{array}{l}\text { Country FE } \\
\text { Time (Quarter) FE }\end{array}$ & $\begin{array}{l}\text { YES } \\
\text { YES }\end{array}$ & $\begin{array}{l}\text { YES } \\
\text { YES }\end{array}$ & $\begin{array}{l}\text { YES } \\
\text { YES }\end{array}$ & $\begin{array}{l}\text { YES } \\
\text { YES }\end{array}$ \\
\hline $\begin{array}{l}\text { R-squared } \\
\text { N. of cases }\end{array}$ & $\begin{array}{r}0.048 \\
71888\end{array}$ & $\begin{array}{r}0.053 \\
48461\end{array}$ & $\begin{array}{r}0.072 \\
17105\end{array}$ & $\begin{array}{r}0.068 \\
26153\end{array}$ \\
\hline $\begin{array}{l}\text { Mean of } \\
\text { dependent } \\
\text { variable }\end{array}$ & -0.0421 & -0.0554 & -0.0410 & -0.0676 \\
\hline
\end{tabular}


Table 4 Robustness checks controling for signaling effect

This table reports the results of regressions that examine the impact of the SNB swap on Hungarian and Polish banks. We estimate alternative versions of the following regression specification:

$\Delta \mathrm{p}_{\mathrm{i}, \mathrm{j}, \mathrm{t}}=\beta_{1} \times S W A P_{j t}^{S N B \mid X}+\beta_{2} \times S w a p D a t e_{t}^{S N B \mid X}+\beta_{3} \times$ SwapSignal $_{j t}^{S N B \mid X}+\phi_{k} \times \Delta \mathrm{p}_{\mathrm{i}, \mathrm{j}, \mathrm{t}-\mathrm{k}}+\alpha \times$ Other $_{\mathrm{t}}+v_{j}+\mu_{t}+\varepsilon_{\mathrm{i}, \mathrm{j}, \mathrm{t}}$ where $\Delta \mathrm{p}_{\mathrm{i}, \mathrm{j}, \mathrm{t}}$ denotes the bank performance measured as the change in the $\ln$ share price of a CEE bank $\mathrm{i}$ in country $\mathrm{j}$ at time $\mathrm{t}$; the variable, $S W A P_{j t}^{S N B \mid X}=S w a p D a t e_{t}^{S N B \mid X} \times S w a p \operatorname{Country}_{j}^{S N B \mid X}$, is +1 for the period and country when the swap lines with country or group $\mathrm{X}$ are active and 0 otherwise and denotes one of the alternative dummy swap lines: SNB-CEE $\left(S W A P_{j t}^{S N B \mid C E E}\right)$ - is a dummy variable taking a one if the bank operates in Hungary for period 2 February 2009-25 January 2010 or in Poland for period 17 November 2008-25 January 2010, SNB-ECB swap line $\left(S W A P_{j t}^{S N B \mid E C B}\right)$ - is a dummy variable taking a one if the bank operates in any country member of Euro zone for period 20 October 2008-25 January 2010, SNB-MNB swap line $\left(S W A P_{j t}^{S N B \mid M N B}\right)$ - is a dummy variable taking a one if the bank operates in Hungary for period 2 February 200925 January 2010, and SNB-NBP swap line $\left(S W A P_{j t}^{S N B \mid N B P}\right)$ is a dummy variable taking a one if the bank operates in Poland for period 17 November 2008-25 January 2010; the dummy variable, SwapDate $t^{S N B \mid X}$, is +1 for the period when the swap lines with country or group $\mathrm{X}$ are active and 0 otherwise; the dummy variable, SwapSignal $_{j t}^{S N B \mid X}$, is a preliminary announcement dummy and take value +1 during the period between announcement and implementation dates of swap lines and 0 otherwise (The SNB-ECB swap line was announced on Wednesday, October 15, 2008 and it became effective on Monday, October 20, 2008. The SNB-NBP swap line was announced on Friday, November 7, 2008 and it became effective on Monday, November 17, 2008. The SNBMNB swap line was announced on Wednesday, January 28, 2009 and it became effective on Monday, February 2, $2009) ; \Delta \mathrm{p}_{\mathrm{i}, \mathrm{j}, \mathrm{t}-\mathrm{k}}$ - lagged ( $\mathrm{k}=1,2$ and 3 ) values of dependent variable; the Other $_{\mathrm{t}}$ captures (macroeconomic) control variables and include $V I X$ - to control for investor sentiment and market volatility; Exchange rate (CHF/EUR) return - to control for movements on FX markets; European banking systems performance (STOXX ${ }^{\circledR}$ Europe 600 Banks index return) - to control for European banking system overall performance. We include country fixed effects $v_{j}$ and time (quarter) fixed effects $\mu_{t}$ in all specifications to control for omitted variables. Standard errors are reported in brackets and account for clustering at the country level. We use $* * *, * *$, and $*$ to denote statistical significance at the $1 \%, 5 \%$, and $10 \%$ levels, respectively.

\begin{tabular}{|c|c|c|c|c|}
\hline Dependent: Bank performance & Model 1 & Model 2 & Model 3 & Model 4 \\
\hline SNB-CEE & $\begin{array}{r}0.2157 * * * \\
(0.0436)\end{array}$ & & & \\
\hline CEE - Date & $\begin{array}{r}0.2870 * * * \\
(0.0956)\end{array}$ & & & \\
\hline $\mathrm{SNB}-\mathrm{ECB}$ & & $\begin{array}{r}-0.0414 \\
(0.0502)\end{array}$ & & \\
\hline ECB - Date & & $\begin{array}{r}0.4892 * * * \\
(0.1523)\end{array}$ & & \\
\hline SNB-MNB & & & $\begin{array}{r}0.2899 * * * \\
(0.0623)\end{array}$ & \\
\hline MNB - Date & & & $\begin{array}{r}0.2875^{* * *} * \\
(0.0972)\end{array}$ & \\
\hline SNB-NBP & & & & $\begin{array}{r}0.1761 \text { ***** } \\
(0.0353)\end{array}$ \\
\hline NBP - Date & & & & $\begin{array}{r}0.3010^{* * *} \\
(0.0992) \\
\end{array}$ \\
\hline $\mathrm{CEE}$ - Signal & $\begin{array}{r}0.2979 \\
(0.1904)\end{array}$ & & & \\
\hline ECB - Signal & & $\begin{array}{r}0.1196 \\
(0.5083)\end{array}$ & & \\
\hline MNB - Signal & & & $\begin{array}{c}0.2796^{*} \\
(0.1537)\end{array}$ & \\
\hline NBP - Signal & & & & $\begin{array}{r}0.3171 \\
(0.2185) \\
\end{array}$ \\
\hline Country FE & Y̌ES & Y YES & Y̌ES & YES \\
\hline Time (Quarter) FE & YES & YES & YES & YES \\
\hline R-squared & 0.048 & 0.048 & 0.048 & 0.048 \\
\hline N. of cases & 71888 & 71888 & 71888 & 71888 \\
\hline Mean of dependent variable & -0.0421 & -0.0421 & -0.0421 & -0.0421 \\
\hline
\end{tabular}


Table 5 Controlling for the other major central banks' swap agreements

This table reports the results of regressions that examine the impact of the SNB swap on Hungarian and Polish banks controlling for the other major central banks' swap agreements. We estimate alternative versions of the following regression specification:

$$
\Delta \mathrm{p}_{\mathrm{i}, \mathrm{j}, \mathrm{t}}=\beta_{1} \times S W A P_{j t}^{S N B \mid C E E}+\beta_{2} \times S W A P_{j t}^{S N B \mid X}+\phi_{k} \times \Delta \mathrm{p}_{\mathrm{i}, \mathrm{j}, \mathrm{t}-\mathrm{k}}+\alpha \times \text { Other }_{\mathrm{t}}+v_{j}+\mu_{t}+\varepsilon_{\mathrm{i}, \mathrm{j}, \mathrm{t}}
$$

where $\Delta \mathrm{p}_{\mathrm{i}, \mathrm{j}, \mathrm{t}}$ denotes the bank performance measured as the change in the $\ln$ share price of a CEE bank i in country $\mathrm{j}$ at time $\mathrm{t}$; the dummy variable, SNB-CEE $\left(S W A P_{j t}^{S N B \mid C E E}\right)$ - is a dummy variable taking a one if the bank operates in Hungary for period 2 February 2009-25 January 2010 or in Poland for period 17 November 2008-25 January 2010; $S W A P_{j t}^{S N B \mid X}$, is +1 for the period when the swap lines with country or group $\mathrm{X}$ are active and 0 otherwise and denotes one of the alternative dummy swap lines: SNB-ECB $\left(S W A P_{j t}^{S N B \mid E C B}\right)-\mathrm{a}$ dummy variable taking a one if SNB has an Liquidity Swap with ECB (20 October 2008-25 January 2010); SNB-USD $\left(\left(S W A P_{j t}^{S N B \mid M U L T 1}\right)\right.$ - a dummy variable taking a one if SNB has an Dollar Liquidity Swap Lines with FED or other banks (12 December 2007-1 February 2010; and May 2010 - 31 December 2012); and SNB-CBs $\left(S W A P_{j t}^{S N B \mid M U L T 2}\right.$ ) - a dummy variable taking a one if SNB has an CHF Liquidity Swap Lines with other central

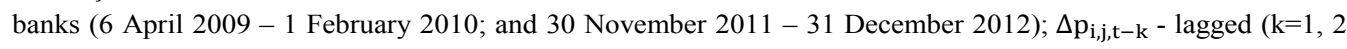
and 3) values of dependent variable; the Other $_{\mathrm{t}}$ captures (macroeconomic) control variables and include VIX - to control for investor sentiment and market volatility; Exchange rate (CHF/EUR) return - to control for movements on FX markets; European banking systems performance (STOXX® Europe 600 Banks index return) - to control for European banking system overall performance. We include country fixed effects $v_{j}$ and time (quarter) fixed effects $\mu_{t}$ in all specifications to control for omitted variables; and $\varepsilon_{\mathrm{i}, \mathrm{j}, \mathrm{t}}$ is the error term. Standard errors are reported in brackets and account for clustering at the country level. We use $* * *, * *$, and $*$ to denote statistical significance at the $1 \%, 5 \%$, and $10 \%$ levels, respectively.

\begin{tabular}{l|rrrr}
\hline \hline Dependent: Bank performance & Model 1 & Model 2 & Model 3 & Model 4 \\
\hline SNB-CEE & $0.2602^{* * *}$ & $0.2601^{* * *}$ & $0.2435^{* * *}$ & $0.2487^{* * *}$ \\
& $(0.0441)$ & $(0.0440)$ & $(0.0357)$ & $(0.0359)$ \\
\hline SNB-ECB & 0.0695 & $0.0692^{*}$ & & \\
SNB-USD & $(0.0441)$ & $(0.0414)$ & & \\
& 0.0998 & & 0.0577 & \\
SNB-CBs & $(0.1237)$ & & $(0.1160)$ & \\
& $-0.1069^{* * *}$ & & & -0.0557 \\
\hline Bank performance (Lag 1) & $(0.0297)$ & & & $(0.0517)$ \\
& $-7.3206^{* *}$ & $-7.3098^{* *}$ & $-7.3097^{* *}$ & $-7.3107^{* *}$ \\
Bank performance (Lag 2) & $(3.1098)$ & $(3.1056)$ & $(3.1096)$ & $(3.1022)$ \\
& $-3.0983^{* * *}$ & $-3.0945^{* * *}$ & $-3.0939^{* * *}$ & $-3.0920^{* * *}$ \\
Bank performance (Lag 3) & $(0.8625)$ & $(0.8597)$ & $(0.8607)$ & $(0.8581)$ \\
& $-1.4413^{*}$ & $-1.4395^{*}$ & $-1.4383^{*}$ & $-1.4375^{*}$ \\
\hline VIX & $(0.8414)$ & $(0.8392)$ & $(0.8406)$ & $(0.8383)$ \\
\hline Exchange rate (CHF/EUR) & $-0.0260^{* * *}$ & $-0.0247^{* * *}$ & $-0.0251^{* * *}$ & $-0.0249^{* * *}$ \\
return & $(0.0061)$ & $(0.0055)$ & $(0.0060)$ & $(0.0054)$ \\
European banking systems & $19.0106^{* * *}$ & $18.9565^{* * *}$ & $18.9923^{* * *}$ & $18.9683 * * *$ \\
performance & $(3.3007)$ & $(3.3234)$ & $(3.2963)$ & $(3.3197)$ \\
\hline Country FE & $16.9306^{* * *}$ & $16.9892^{* * *}$ & $16.9751^{* * *}$ & $16.9706^{* * *}$ \\
Time (Quarter) FE & $(5.9717)$ & $(5.9498)$ & $(5.9699)$ & $(5.9373)$ \\
\hline R-squared & YES & YES & YES & YES \\
N. of cases & YES & YES & YES & YES \\
\hline Mean of dependent variable & -0.0421 & -0.0421 & -0.0421 & -0.0421 \\
\hline \hline
\end{tabular}


Table 6 Controlling for the level of foreign currency exposure (FX)

This table reports the results of regressions that examine the impact of the SNB swap on Hungarian and Polish banks controlling for the level of foreign currency exposure. We estimate alternative versions of the following regression specification:

$\Delta \mathrm{p}_{\mathrm{i}, \mathrm{j}, \mathrm{t}}=\beta_{1} \times S W A P_{j t}^{S N B \mid C E E}+\beta_{2} \times F X_{\mathrm{i}, \mathrm{j}, t}+\beta_{3} \times S W A P_{j t}^{S N B \mid C E E} * F X_{\mathrm{i}, \mathrm{j}, t}+\phi_{k} \times \Delta \mathrm{p}_{\mathrm{i}, \mathrm{j}, \mathrm{t}-\mathrm{k}}+\alpha \times$ Other $_{\mathrm{t}}+v_{j}+\mu_{t}+\varepsilon_{\mathrm{i}, \mathrm{j}, \mathrm{t}}$ where $\Delta \mathrm{p}_{\mathrm{i}, \mathrm{j}, \mathrm{t}}$ denotes the bank performance measured as the change in the ln share price of a CEE bank $\mathrm{i}$ in country $\mathrm{j}$ at time $\mathrm{t}$; the dummy variable, SNB-CEE $\left(S W A P_{j t}^{S N B \mid C E E}\right)$ - is a dummy variable taking a one if the bank operates in Hungary for period 2 February 2009-25 January 2010 or in Poland for period 17 November 2008-25 January 2010; FX denotes one of the alternative measure for the level of foreign currency exposure: Share of assets in $\mathrm{CHF}=($ Assets in $\mathrm{CHF} / \mathrm{Total}$ assets $) ;$ Share of assets in foreign currencies $=($ Total assets in foreign currencies/ Total assets); Net position in $\mathrm{CHF}=$ [(Assets in CHF - Liabilities in CHF)/Total assets]; Net position in foreign currencies $=[($ Total assets in foreign currencies - Total liabilities in foreign currencies $) /$ Total assets]; $S W A P_{j t}^{S N B \mid C E E} * F X_{\mathrm{i}, \mathrm{j}, t}$ denotes the interaction between SNB-CEE swap variable and $F X$ variables; $\Delta \mathrm{p}_{\mathrm{i}, \mathrm{j}, \mathrm{t}-\mathrm{k}}$ - lagged $(\mathrm{k}=1,2$ and 3$)$ values of dependent variable; the Other $_{\mathrm{t}}$ captures (macroeconomic) control variables and include $V I X$ - to control for investor sentiment and market volatility; Exchange rate (CHF/EUR) return - to control for movements on FX markets; European banking systems performance (STOXX®) Europe 600 Banks index return) - to control for European banking system overall performance. We include country fixed effects $v_{j}$ and time (quarter) fixed effects $\mu_{t}$ in all specifications to control for omitted variables; and $\varepsilon_{\mathrm{i}, \mathrm{j}, \mathrm{t}}$ is the error term. Standard errors are reported in brackets and account for clustering at the country level. We use $* * *$, $* *$, and * to denote statistical significance at the $1 \%, 5 \%$, and $10 \%$ levels, respectively.

\begin{tabular}{|c|c|c|c|c|}
\hline Dependent: Bank performance & Model 1 & Model 2 & Model 3 & Model 4 \\
\hline SNB-CEE & $\begin{array}{r}0.2973 * * * \\
(0.0274)\end{array}$ & $\begin{array}{r}0.1798 * * * \\
(0.0265)\end{array}$ & $\begin{array}{r}0.3060 * * * \\
(0.0327)\end{array}$ & $\begin{array}{r}0.2485 * * * \\
(0.0375)\end{array}$ \\
\hline Share of assets in $\mathrm{CHF}$ & $\begin{array}{r}-0.0165 \\
(0.0897)\end{array}$ & & & \\
\hline $\begin{array}{l}\text { SNB-CEE * Share of assets in } \\
\text { CHF }\end{array}$ & $\begin{array}{r}0.0063 \\
(0.1146)\end{array}$ & & & \\
\hline $\begin{array}{l}\text { Share of assets in foreign } \\
\text { currencies }\end{array}$ & & $\begin{array}{r}-0.0327 * \\
(0.0178)\end{array}$ & & \\
\hline $\begin{array}{l}\text { SNB-CEE * Share of assets in } \\
\text { foreign currencies }\end{array}$ & & $\begin{array}{r}0.1631 * * * \\
(0.0225)\end{array}$ & & \\
\hline Net position in CHF & & & $\begin{array}{r}-0.0328 \\
(0.1015)\end{array}$ & \\
\hline $\begin{array}{l}\text { SNB-CEE * } \\
\text { Net position in CHF }\end{array}$ & & & $\begin{array}{r}-0.0953 \\
(0.1023)\end{array}$ & \\
\hline $\begin{array}{l}\text { Net position in foreign } \\
\text { currencies }\end{array}$ & & & & $\begin{array}{r}0.0622 \\
(0.0690)\end{array}$ \\
\hline $\begin{array}{l}\text { SNB-CEE * Net position in } \\
\text { foreign currencies }\end{array}$ & & & & $\begin{array}{r}-0.0769 \\
(0.0603) \\
\end{array}$ \\
\hline Bank performance (Lag 1) & $\begin{array}{l}-3.8056 \\
(2.6466)\end{array}$ & $\begin{array}{r}-7.6111^{* *} \\
(3.1965)\end{array}$ & $\begin{array}{r}-3.8060 \\
(2.6465)\end{array}$ & $\begin{array}{r}-7.6088^{* *} \\
(3.1979)\end{array}$ \\
\hline Bank performance ( $\operatorname{Lag} 2)$ & $\begin{array}{r}-2.9104 * * * \\
(0.6887)\end{array}$ & $\begin{array}{r}-3.0816 * * * \\
(0.9029)\end{array}$ & $\begin{array}{r}-2.9109 * * * \\
(0.6896)\end{array}$ & $\begin{array}{r}-3.0784 * * * \\
(0.9033)\end{array}$ \\
\hline Bank performance (Lag 3) & $\begin{array}{r}-1.0967 * \\
(0.6090)\end{array}$ & $\begin{array}{r}-1.4412 * \\
(0.8281)\end{array}$ & $\begin{array}{r}-1.0975^{*} \\
(0.6099)\end{array}$ & $\begin{array}{r}-1.4383 * \\
(0.8272)\end{array}$ \\
\hline VIX & $\begin{array}{r}-0.0250^{* * *} \\
(0.0066)\end{array}$ & $\begin{array}{r}-0.0242^{* * *} \\
(0.0054)\end{array}$ & $\begin{array}{r}-0.0250^{* * *} \\
(0.0065)\end{array}$ & $\begin{array}{r}-0.0242 * * * \\
(0.0054)\end{array}$ \\
\hline $\begin{array}{l}\text { Exchange rate }(\mathrm{CHF} / \mathrm{EUR}) \\
\text { return }\end{array}$ & $\begin{array}{r}23.2772 * * * \\
(2.8088)\end{array}$ & $\begin{array}{r}18.7041^{* * *} \\
(3.4205)\end{array}$ & $\begin{array}{r}23.2776 * * * \\
(2.8094)\end{array}$ & $\begin{array}{r}18.7057^{* * * *} \\
(3.4204)\end{array}$ \\
\hline $\begin{array}{l}\text { European banking systems } \\
\text { performance }\end{array}$ & $\begin{array}{r}25.8102 * * * \\
(6.7100) \\
\end{array}$ & $\begin{array}{r}17.0311 * * * \\
(6.0919)\end{array}$ & $\begin{array}{r}25.8100^{* * * *} \\
(6.7100) \\
\end{array}$ & $\begin{array}{r}17.0310^{* * * *} \\
(6.0919)\end{array}$ \\
\hline Country FE & YES & YES & YES & $\mathrm{YES}$ \\
\hline Time (Quarter) FE & YES & YES & YES & YES \\
\hline R-squared & 0.081 & 0.048 & 0.081 & 0.048 \\
\hline N. of cases & 32756 & 69425 & 32756 & 69425 \\
\hline Mean of dependent variable & -0.0421 & -0.0421 & -0.0421 & -0.0421 \\
\hline
\end{tabular}


Table 7 Controlling for funding structure

This table reports the results of regressions that examine the impact of the SNB swap on Hungarian and Polish banks controlling for funding structure. We estimate alternative versions of the following regression specification:

$$
\Delta \mathrm{p}_{\mathrm{i}, \mathrm{j}, \mathrm{t}}=\beta_{1} \times S W A P_{j t}^{S N B \mid C E E}+\beta_{2} \times \text { Fund_struct }_{\mathrm{i}, \mathrm{j}, t}+\beta_{3} \times S W A P_{j t}^{S N B \mid C E E} * \text { Fund_struct }_{\mathrm{i}, \mathrm{j}, t}+\phi_{k} \times \Delta \mathrm{p}_{\mathrm{i}, \mathrm{j}, \mathrm{t}-\mathrm{k}}+\alpha \times \text { Other }_{\mathrm{t}}+v_{j}+\mu_{t}+\varepsilon_{\mathrm{i}, \mathrm{j}, \mathrm{t}}
$$

where $\Delta \mathrm{p}_{\mathrm{i}, \mathrm{j}, \mathrm{t}}$ denotes the bank performance measured as the change in the ln share price of a CEE bank $\mathrm{i}$ in country $\mathrm{j}$ at time $\mathrm{t}$; the dummy variable, SNB-CEE $\left(S W A P_{j t}^{S N B \mid C E E}\right)$ - is a dummy variable taking a one if the bank operates in Hungary for period 2 February 2009-25 January 2010 or in Poland for period 17 November 2008-25 January 2010; Fund_struct is: Funding fragility - the ratio between the sum of deposits from other banks, other deposits, and short term borrowing over total deposits plus money market and short-term funding; $S W A P_{j t}^{S N B \mid C E E} * F_{\text {Fund_struct }}{ }_{\mathrm{i}, \mathrm{c}, t}$ denotes the interaction between SNBCEE swap variable and Funding structure variables; $\Delta \mathrm{p}_{\mathrm{i}, \mathrm{j}, \mathrm{t}-\mathrm{k}}$ - lagged $(\mathrm{k}=1,2$ and 3$)$ values of dependent variable; the Other $_{\mathrm{t}}$ captures (macroeconomic) control variables and include VIX - to control for investor sentiment and market volatility; Exchange rate (CHF/EUR) return - to control for movements on FX markets; European banking systems performance (STOXX ${ }^{\circledR}$ Europe 600 Banks index return) - to control for European banking system overall performance. We include country fixed effects $v_{j}$ and time (quarter) fixed effects $\mu_{t}$ in all specifications to control for omitted variables; and $\varepsilon_{\mathrm{i}, \mathrm{j}, \mathrm{t}}$ is the error term. Standard errors are reported in brackets and account for clustering at the country level. We use $* * *, * *$, and $*$ to denote statistical significance at the $1 \%, 5 \%$, and $10 \%$ levels, respectively.

\begin{tabular}{l|r}
\hline \hline Dependent: Bank performance & Model 2 \\
\hline SNB-CEE & $0.1338^{* * *}$ \\
& $(0.0322)$ \\
\hline Funding fragility & $-0.1569^{* * *}$ \\
& $(0.0539)$ \\
SNB-CEE * Funding fragility & $0.2877^{* * *}$ \\
& $(0.0919)$ \\
\hline Bank performance (Lag 1) & $-7.3246^{* *}$ \\
& $(3.1140)$ \\
Bank performance (Lag 2) & $-3.0806^{* * *}$ \\
& $(0.8727)$ \\
Bank performance (Lag 3) & $-1.4824^{*}$ \\
& $(0.8252)$ \\
\hline VIX & $-0.0246^{* * *}$ \\
& $(0.0055)$ \\
Exchange rate (CHF/EUR) return & $18.9489^{* * *}$ \\
& $(3.3273)$ \\
European banking systems & $17.0225^{* * *}$ \\
performance & $(5.9545)$ \\
\hline Country FE & YES \\
Time (Quarter) FE & YES \\
\hline R-squared & 0.048 \\
N. of cases & 71398 \\
\hline Mean of dependent variable & -0.0421 \\
\hline
\end{tabular}


Table 8 Controlling for degree of international connectedness

This table reports the results of regressions that examine the impact of the SNB swap on Hungarian and Polish banks controlling for degree of international connectedness. We estimate alternative versions of the following regression specification:

$$
\Delta \mathrm{p}_{\mathrm{i}, \mathrm{j}, \mathrm{t}}=\beta_{1} \times S W A P_{j t}^{S N B \mid C E E}+\beta_{2} \times \text { Connect }_{\mathrm{i}, \mathrm{j}, t}+\beta_{3} \times S W A P_{j t}^{S N B \mid C E E} * \text { Connect }_{\mathrm{i}, \mathrm{j}, t}+\phi_{k} \times \Delta \mathrm{p}_{\mathrm{i}, \mathrm{j}, \mathrm{t}-\mathrm{k}}+\alpha \times \text { Other }_{\mathrm{t}}+v_{j}+\mu_{t}+\varepsilon_{\mathrm{i}, \mathrm{j}, \mathrm{t}}
$$

where $\Delta \mathrm{p}_{\mathrm{i}, \mathrm{j}, \mathrm{t}}$ denotes the bank performance measured as the change in the ln share price of a CEE bank $\mathrm{i}$ in country $\mathrm{j}$ at time $\mathrm{t}$; the dummy variable SNB-CEE $\left(S W A P_{j t}^{S N B \mid C E E}\right)$ - is a dummy variable taking a one if the bank operates in Hungary for period 2 February 2009-25 January 2010 or in Poland for period 17 November 2008-25 January 2010; Connect denotes one of the alternative measure for degree of international connectedness: Foreign ownership is a dummy variable taking a one if $50 \%$ or more of banks' shares are owned by foreigners; Member of Banking group is a dummy variable taking a one if the bank is a subsidiary of a International banking group with at least 5 subsidiaries in CEE region; $S W A P_{j t}^{S N B \mid C E E} *$ Connect $_{\mathrm{i}, \mathrm{j}, t}$ denotes the interaction between SNB-CEE swap variable and Degree of international connectedness variables; $\Delta \mathrm{p}_{\mathrm{i}, \mathrm{j}, \mathrm{t}-\mathrm{k}}$ - lagged $(\mathrm{k}=1,2$ and 3$)$ values of dependent variable; the Other $_{\mathrm{t}}$ captures (macroeconomic) control variables and include VIX - to control for investor sentiment and market volatility; Exchange rate (CHF/EUR) return - to control for movements on FX markets; European banking systems performance (STOXX ${ }^{\circledR}$ Europe 600 Banks index return) - to control for European banking system overall performance. We include country fixed effects $v_{j}$ and time (quarter) fixed effects $\mu_{t}$ in all specifications to control for omitted variables; and $\varepsilon_{i, j, t}$ is the error term. Standard errors are reported in brackets and account for clustering at the country level. We use ${ }^{* * *}, * *$, and $*$ to denote statistical significance at the $1 \%, 5 \%$, and $10 \%$ levels, respectively.

\begin{tabular}{l|rr}
\hline \hline Dependent: Bank performance & Model 1 & Model 2 \\
\hline SNB-CEE & $0.3198^{* * *}$ & $0.2433^{* * *}$ \\
& $(0.0727)$ & $(0.0338)$ \\
\hline Foreign ownership & 0.0324 & \\
SNB-CEE * Foreign ownership & $(0.0208)$ & \\
& $-0.1040^{*}$ & \\
Member of Banking group & $(0.0729)$ & \\
& & 0.0132 \\
SNB-CEE * Member of Banking & & $(0.0178)$ \\
group & & $0.0225^{*}$ \\
\hline Bank performance (Lag 1) & $-7.3124^{* *}$ & $-7.0212)$ \\
& $(3.1080)$ & $\left(3.1063^{* *}\right.$ \\
Bank performance (Lag 2) & $-3.0973^{* * *}$ & $-3.0931^{* * *}$ \\
& $(0.8607)$ & $(0.8591)$ \\
Bank performance (Lag 3) & $-1.4421^{*}$ & $-1.4384^{*}$ \\
& $(0.8414)$ & $(0.8395)$ \\
\hline VIX & $-0.0247^{* * *}$ & $-0.0247^{* * *}$ \\
& $(0.0055)$ & $(0.0055)$ \\
Exchange rate (CHF/EUR) return & $18.9671^{* * *}$ & $18.9654^{* * *}$ \\
& $(3.3193)$ & $(3.3184)$ \\
European banking systems & $16.9884^{* * *}$ & $16.9888^{* * *}$ \\
performance & $(5.9496)$ & $(5.9497)$ \\
\hline Country FE & YES & YES \\
Time (Quarter) FE & YES & YES \\
\hline R-squared & 0.048 & 0.048 \\
N. of cases & 71888 & 71888 \\
\hline Mean of dependent variable & -0.0421 & -0.0421 \\
\hline \hline
\end{tabular}


$\underline{\text { Table } 9}$ Controlling for capital structure

This table reports the results of regressions that examine the impact of the SNB swap on Hungarian and Polish banks controlling for capital structure. We estimate alternative versions of the following regression specification:

$$
\Delta \mathrm{p}_{\mathrm{i}, \mathrm{j}, \mathrm{t}}=\beta_{1} \times S W A P_{j t}^{S N B \mid C E E}+\beta_{2} \times \text { Cap_struct }_{\mathrm{i}, \mathrm{j}, t}+\beta_{3} \times S W A P_{j t}^{S N B \mid C E E} * \text { Cap_struct }_{\mathrm{i}, \mathrm{j}, t}+\phi_{k} \times \Delta \mathrm{p}_{\mathrm{i}, \mathrm{j}, \mathrm{t}-\mathrm{k}}+\alpha \times \text { Other }_{\mathrm{t}}+v_{j}+\mu_{t}+\varepsilon_{\mathrm{i}, \mathrm{j}, \mathrm{t}}
$$

where $\Delta \mathrm{p}_{\mathrm{i}, \mathrm{j}, \mathrm{t}}$ denotes the bank performance measured as the change in the ln share price of a CEE bank $\mathrm{i}$ in country $\mathrm{j}$ at time $\mathrm{t}$; the dummy variable SNB-CEE $\left(S W A P_{j t}^{S N B \mid C E E}\right)$ - is a dummy variable taking a one if the bank operates in Hungary for period 2 February 2009-25 January 2010 or in Poland for period 17 November 2008-25 January 2010; Cap_struct denotes one of the alternative capital structure measure: Cap_struct1 = Total capital Ratio; Cap_struct2 $=$ Tier 1 Ratio; $S W A P_{j t}^{S N B \mid C E E} *$ Cap_struct $_{\mathrm{i}, \mathrm{j}, t}$ denotes the interaction between SNB-CEE swap variable and Capital structure variables; $\Delta \mathrm{p}_{\mathrm{i}, \mathrm{j}, \mathrm{t}-\mathrm{k}}$ - lagged $(\mathrm{k}=1,2$ and 3$)$ values of dependent variable; the Other $r_{\mathrm{t}}$ captures (macroeconomic) control variables and include VIX - to control for investor sentiment and market volatility; Exchange rate (CHF/EUR) return - to control for movements on FX markets; European banking systems performance (STOXX ${ }^{\circledR}$ Europe 600 Banks index return) - to control for European banking system overall performance. We include country fixed effects $v_{j}$ and time (quarter) fixed effects $\mu_{t}$ in all specifications to control for omitted variables; and $\varepsilon_{i, j, t}$ is the error term. Standard errors are reported in brackets and account for clustering at the country level. We use $* * *, * *$, and * to denote statistical significance at the $1 \%$, $5 \%$, and $10 \%$ levels, respectively.

\begin{tabular}{|c|c|c|}
\hline Dependent: Bank performance & Model 1 & Model 2 \\
\hline SNB-CEE & $\begin{array}{r}0.5691 * * * \\
(0.1378)\end{array}$ & $\begin{array}{r}0.4301 * * * \\
(0.0734)\end{array}$ \\
\hline Cap_struct1 & $\begin{array}{r}0.0015 \\
(0.0025)\end{array}$ & \\
\hline SNB-CEE * Cap_struct1 & $\begin{array}{r}-0.0243 * * \\
(0.0120)\end{array}$ & \\
\hline Cap_struct2 & & $\begin{array}{r}0.0021 \\
(0.0019)\end{array}$ \\
\hline SNB-CEE * Cap_struct 2 & & $\begin{array}{r}-0.0148 * * \\
(0.0059)\end{array}$ \\
\hline Bank performance (Lag 1) & $\begin{array}{r}-7.2572 * * \\
(3.2044)\end{array}$ & $\begin{array}{r}-2.9586 \\
(3.4458)\end{array}$ \\
\hline Bank performance (Lag 2) & $\begin{array}{r}-3.1185 * * * \\
(0.9599)\end{array}$ & $\begin{array}{r}-2.7285^{* * * *} \\
(0.8322)\end{array}$ \\
\hline Bank performance (Lag 3) & $\begin{array}{r}-1.4906^{*} \\
(0.8606)\end{array}$ & $\begin{array}{r}-0.3520 \\
(0.7487)\end{array}$ \\
\hline VIX & $\begin{array}{r}-0.0255^{* * *} \\
(0.0059)\end{array}$ & $\begin{array}{r}-0.0269^{* * *} \\
(0.0065)\end{array}$ \\
\hline Exchange rate (CHF/EUR) return & $\begin{array}{r}18.8416^{* * *} \\
(3.0405)\end{array}$ & $\begin{array}{r}19.7485 * * * \\
(3.2985)\end{array}$ \\
\hline $\begin{array}{l}\text { European banking systems } \\
\text { performance }\end{array}$ & $\begin{array}{r}18.1301 * * * \\
(5.9113)\end{array}$ & $\begin{array}{r}22.1967 * * * \\
(6.5006) \\
\end{array}$ \\
\hline $\begin{array}{l}\text { Country FE } \\
\text { Time (Quarter) FE }\end{array}$ & $\begin{array}{l}\text { YES } \\
\text { YES }\end{array}$ & $\begin{array}{l}\text { YES } \\
\text { YES }\end{array}$ \\
\hline $\begin{array}{l}\text { R-squared } \\
\text { N. of cases }\end{array}$ & $\begin{array}{r}0.051 \\
65453\end{array}$ & $\begin{array}{r}0.074 \\
46039\end{array}$ \\
\hline Mean of dependent variable & -0.0421 & -0.0421 \\
\hline
\end{tabular}


Appendix 1 List of banks

\begin{tabular}{|c|c|c|c|c|}
\hline Bank name & $\begin{array}{c}\text { Bank code } \\
\text { (BankScope) }\end{array}$ & Host country & $\begin{array}{l}\text { Total assets in } 2008 \\
\text { EUR millions }\end{array}$ & Ownership \\
\hline Hypo Alpe-Adria-Bank a.d. Banja Luka & 29065 & Bosnia and Herzegovina & 979 & Foreign \\
\hline Intesa Sanpaolo Banka d.d. Bosna i Hercegovina & 46742 & Bosnia and Herzegovina & 517 & Foreign \\
\hline NLB Banka d.d. & 45854 & Bosnia and Herzegovina & 406 & Foreign \\
\hline Sparkasse Bank dd & 40547 & Bosnia and Herzegovina & 269 & Foreign \\
\hline UniCredit Bank dd & 46705 & Bosnia and Herzegovina & 1,688 & Foreign \\
\hline Corporate Commercial Bank AD & 15330 & Bulgaria & 1,091 & Domestic \\
\hline First Investment Bank AD & 43151 & Bulgaria & 2,212 & Domestic \\
\hline Erste \& Steierm\%orkische Bank dd & 31492 & Croatia & 6,394 & Foreign \\
\hline Hrvatska Postanska Bank DD & 27044 & Croatia & 2,040 & Domestic \\
\hline Jadranska Banka dd & 47953 & Croatia & 328 & Domestic \\
\hline Podravska Banka & 47433 & Croatia & 388 & Domestic \\
\hline $\begin{array}{l}\text { Privredna Banka Zagreb d.d-Privredna Banka Zagreb } \\
\text { Group }\end{array}$ & 31139 & Croatia & 9,927 & Foreign \\
\hline Zagrebacka Banka dd & 33081 & Croatia & 14,501 & Foreign \\
\hline Komercni Banka & 42320 & Czech Republic & 25,965 & Foreign \\
\hline FHB Mortgage Bank Plc-FHB Jelzalogbank Nyrt. & 18740 & Hungary & 2,637 & Domestic \\
\hline OTP Bank Plc & 44850 & Hungary & 35,821 & Domestic \\
\hline AS DNB Banka & 33110 & Latvia & 3,179 & Foreign \\
\hline AB DNB Bankas & 38058 & Lithuania & 4,092 & Foreign \\
\hline Siauliu Bankas & 38681 & Lithuania & 610 & Domestic \\
\hline Komercijalna Banka A.D. Skopje & 35919 & Macedonia (FYROM) & 909 & Domestic \\
\hline Stopanska Banka a.d. Skopje & 30961 & Macedonia (FYROM) & 981 & Foreign \\
\hline Stopanska Banka AD, Bitola & 45348 & Macedonia (FYROM) & 112 & Domestic \\
\hline TTK Banka AD Skopje & 25280 & Macedonia (FYROM) & 102 & Domestic \\
\hline Hipotekarna Banka ad Podgorica & 28971 & Montenegro & 75 & Domestic \\
\hline Bank BPH SA & 31077 & Poland & 8,898 & Foreign \\
\hline Bank Handlowy w Warszawie S.A. & 30746 & Poland & 10,323 & Foreign \\
\hline Bank Millennium & 45307 & Poland & 11,428 & Foreign \\
\hline Bank Polska Kasa Opieki SA-Bank Pekao SA & 31008 & Poland & 32,010 & Foreign \\
\hline Bank Zachodni WBK S.A. & 32473 & Poland & 13,934 & Foreign \\
\hline BNP Paribas Bank Polska SA & 11560 & Poland & 4,825 & Foreign \\
\hline ING Bank Slaski S.A. - Capital Group & 48129 & Poland & 16,888 & Foreign \\
\hline Kredyt Bank SA & 48171 & Poland & 9,396 & Foreign \\
\hline Nordea Bank Polska SA & 48321 & Poland & 3,820 & Foreign \\
\hline $\begin{array}{l}\text { Powszechna Kasa Oszczednosci Bank Polski SA - } \\
\text { PKO BP SA }\end{array}$ & 33088 & Poland & 32,663 & Domestic \\
\hline BRD-Groupe Societe Generale SA & 36742 & Romania & 12,910 & Foreign \\
\hline Transilvania Bank-Banca Transilvania SA & 44741 & Romania & 4,348 & Domestic \\
\hline AIK Banka ad Nis & 16829 & Serbia & 953 & Domestic \\
\hline Komercijalna Banka A.D. Beograd & 12565 & Serbia & 1,952 & Domestic \\
\hline Vseobecna Uverova Banka a.s. & 35884 & Slovakia & 11,232 & Foreign \\
\hline OTP Banka Slovensko, as & 38552 & Slovakia & 1,621 & Foreign \\
\hline Prima banka Slovensko a.s. & 44132 & Slovakia & 2,715 & Foreign \\
\hline Sberbank Slovensko, as & 42553 & Slovakia & 1,530 & Foreign \\
\hline Tatra Banka a.s. & 37500 & Slovakia & 10,551 & Foreign \\
\hline Abanka Vipa dd & 35837 & Slovenia & 3,883 & Domestic \\
\hline Nova Kreditna Banka Maribor d.d. & 31186 & Slovenia & 5,490 & Domestic \\
\hline $\begin{array}{l}\text { Joint-Stock Commercial Bank for Social } \\
\text { Development - Ukrsotsbank }\end{array}$ & 46068 & Ukraine & 4,607 & Foreign \\
\hline Raiffeisen Bank Aval & 46840 & Ukraine & 6,314 & Foreign \\
\hline
\end{tabular}


Appendix 2 Definition of all variables

\begin{tabular}{|c|c|c|}
\hline Variable & Definition & Source \\
\hline Bank performance & $\begin{array}{l}\text { Daily stock return calculated as } \Delta \mathrm{p}_{\mathrm{i}, \mathrm{j}, \mathrm{t}}=\ln \left(P_{i, j, t}-P_{i, j, t-1}\right) \text {, where } P_{i, j, t} \text { denotes the daily stock price for bank } i \text { in } \\
\text { country } j \text { for day } t\end{array}$ & Thomson Reuters \\
\hline SNB-CEE & $\begin{array}{l}\text { A dummy variable taking a one if the bank operates in Hungary for period } 28 \text { January } 2009-25 \text { January } 2010 \text { or in } \\
\text { Poland for period } 7 \text { November } 2008-25 \text { January } 2010\end{array}$ & SNB press releases \\
\hline SNB-ECB & $\begin{array}{l}\text { A dummy variable taking a one if the bank operates in any country member of Euro zone for period } 16 \text { October } \\
2008-25 \text { January } 2010 \text {; }\end{array}$ & SNB press releases \\
\hline SNB-MNB & A dummy variable taking a one if the bank operates in Hungary for period 28 January 2009-25 January 2010; & SNB press releases \\
\hline SNB-NBP & A dummy variable taking a one if the bank operates in Poland for period 7 November 2008-25 January 2010 & SNB press releases \\
\hline SNB-USD & $\begin{array}{l}\text { A dummy variable taking a one if SNB has an Dollar Liquidity Swap Lines with FED or other banks (12 } \\
\text { December 2007-1 February 2010; and May 2010 - 31 December 2012) }\end{array}$ & SNB press releases \\
\hline SNB-CBs & $\begin{array}{l}\text { A dummy variable taking a one if SNB has an CHF Liquidity Swap Lines with other central banks (6 April } 2009 \text { - } \\
1 \text { February } 2010 \text {; and } 30 \text { November } 2011 \text { - } 31 \text { December 2012) }\end{array}$ & SNB press releases \\
\hline SwapDate & $\begin{array}{l}\text { A dummy variable taking a one for the period when the swap lines with country or group } \mathrm{X} \text { are active and } 0 \\
\text { otherwise; the dummy variable }\end{array}$ & SNB press releases \\
\hline SwapCountry & A dummy variable taking a one for the country or group $X$ which had a swap lines with SNB and 0 otherwise & SNB press releases \\
\hline SNB-Signal & $\begin{array}{l}\text { A dummy variable is a preliminary announcement dummy and take value }+1 \text { for the previous } 5 \text { working days to } \\
\text { the period and country when the swap lines with country or group } X \text { are active and } 0 \text { otherwise }\end{array}$ & SNB press releases \\
\hline $\begin{array}{l}\text { Share of assets in } \\
\text { CHF }\end{array}$ & Assets in $\mathrm{CHF} /$ Total assets & Annual Reports \\
\hline $\begin{array}{l}\text { Share of assets in } \\
\text { foreign currencies }\end{array}$ & Total assets in foreign currencies/ Total assets & Annual Reports \\
\hline Net position in $\mathrm{CHF}$ & (Assets in $\mathrm{CHF}$ - Liabilities in $\mathrm{CHF}$ )/Total assets & Annual Reports \\
\hline $\begin{array}{l}\text { Net position in } \\
\text { foreign currencies }\end{array}$ & (Total assets in foreign currencies - Total liabilities in foreign currencies)/Total assets & Annual Reports \\
\hline Funding fragility & $\begin{array}{l}\text { The ratio between the sum of deposits from other banks, other deposits, and short term borrowing over total } \\
\text { deposits plus money market and short-term funding }\end{array}$ & Bureau van Dijk - BankScope \\
\hline Foreign ownership & A dummy variable taking a one if $50 \%$ or more of banks' shares are owned by foreigners & Bureau van Dijk - BankScope \\
\hline $\begin{array}{l}\text { Member of Banking } \\
\text { group }\end{array}$ & $\begin{array}{l}\text { A dummy variable taking a one if the bank is a subsidiary of a International banking group with at least } 5 \\
\text { subsidiaries in CEE region }\end{array}$ & Annual Reports \\
\hline Cap_struct1 & Total capital Ratio & Bureau van Dijk - BankScope \\
\hline Cap_struct2 & Tier 1 Ratio & Bureau van Dijk - BankScope \\
\hline VIX & VIX measures market expectation of near term volatility conveyed by stock index option prices & Federal Reserve Economic Data \\
\hline $\begin{array}{l}\text { Exchange rate } \\
\text { (CHF/EUR) return }\end{array}$ & Swiss franc/EUR exchange rate return & Thomson Reuters \\
\hline $\begin{array}{l}\text { European banking } \\
\text { systems performance }\end{array}$ & Measured using STOXX ${ }^{\circledR}$ Europe 600 Banks index return & Thomson Reuters \\
\hline
\end{tabular}


Appendix 3 Summary statistics

Panel A - Stock returns of banks

\begin{tabular}{c|cc}
\hline \hline Year & $\begin{array}{c}\text { Daily stock return } \\
\text { (\%, average) }\end{array}$ & $\begin{array}{c}\text { Annual stock return } \\
\text { (\%, average) }\end{array}$ \\
\hline $\mathbf{2 0 0 5}$ & 0.0676 & 14.7881 \\
\hline $\mathbf{2 0 0 6}$ & 0.0380 & 7.8019 \\
\hline $\mathbf{2 0 0 7}$ & 0.0472 & 11.9458 \\
\hline $\mathbf{2 0 0 8}$ & -0.2886 & -68.0292 \\
\hline $\mathbf{2 0 0 9}$ & 0.0443 & 11.8574 \\
\hline $\mathbf{2 0 1 0}$ & -0.0151 & -4.0578 \\
\hline $\mathbf{2 0 1 1}$ & -0.1029 & -29.2377 \\
\hline $\mathbf{2 0 1 2}$ & -0.0382 & -10.8925 \\
\hline Total & -0.0421 & -10.8691 \\
\hline \hline
\end{tabular}

Panel B - Descriptive statistics of variables

\begin{tabular}{l|ccccc}
\hline \multicolumn{1}{c|}{ Variables } & Obs & Mean & Std. Dev. & Min & Max \\
\hline Bank performance (\%) & 76139 & -0.0421 & 2.2518 & -9.5676 & 8.8138 \\
\hline Share of assets in CHF & 37036 & 0.1180 & 0.1350 & 0.0000 & 0.4441 \\
\hline Share of assets in foreign currencies & 91791 & 0.4254 & 0.4916 & 0.0079 & 8.3900 \\
\hline Net position in CHF & 37036 & 0.0581 & 0.0979 & -0.0210 & 0.4404 \\
\hline Net position in foreign currencies & 91791 & 0.0287 & 0.1051 & -0.3597 & 0.5417 \\
\hline Funding fragility (\%) & 96481 & 36.3982 & 16.5901 & 11.9630 & 100.0000 \\
\hline Cap_struct1 (Total capital Ratio (\%)) & 84489 & 15.0315 & 5.1391 & 8.6300 & 41.5500 \\
\hline Cap_struct1 (Tier 1 Ratio (\%)) & 58425 & 13.8669 & 6.1704 & 5.5100 & 41.7400 \\
\hline VIX & 94611 & 21.4994 & 10.6145 & 9.8900 & 80.8600 \\
\hline Exchange rate (CHF/EUR) return & 95221 & 0.0000 & 0.0072 & -0.0325 & 0.2463 \\
\hline European banking systems performance & 98042 & -0.0002 & 0.0202 & -0.1039 & 0.1746 \\
\hline \hline
\end{tabular}




\section{Recent SNB Working Papers}

2015-7 Alin Marius Andries, Andreas M. Fischer and Pinar Yeşin: The impact of international swap lines on stock returns of banks in emerging markets.

2015-6 Jens H.E. Christensen an Signe Krogstrup: Transmission of Quantitative Easing: The Role of Central Bank Reserves

2015-5 Petra Gerlach-Kristen and Seán Lyons: Mortgage arrears in Europe: The impact of monetary and macroprudential policies.

2015-4 Reto Foellmi, Sandra Hanslin and Andreas Kohler: A dynamic North-South model of demand-induced product cycles.

2015-3 Katarina Juselius and Katrin Assenmacher: Real exchange rate persistence: The case of the Swiss franc-US dollar rate.

2015-2 Lucas Marc Fuhrer, Basil Guggenheim and Silvio Schumacher: Re-use of collateral in the repo market.

2015-1 Pinar Yeşin: Capital flow waves to and from Switzerland before and after the financial crisis.

2014-13 Thomas Nitschka: Have investors been looking for exposure to specific countries since the global financial crisis? - Insights from the Swiss franc bond market.

2014-12 Christian Grisse and Thomas Nitschka: Exchange rate returns and external adjustment: evidence from Switzerland.

2014-11 Rina Rosenblatt-Wisch and Rolf Scheufele: Quantification and characteristics of household inflation expectations in Switzerland.
2014-10 Gregor Bäurle and Daniel Kaufmann: Exchange rate and price dynamics in a small open economy - the role of the zero lower bound and monetary policy regimes.

2014-9 Matthias Gubler and Christoph Sax: Skill-Biased Technological Change and the Real Exchange Rate.

2014-8 Tommaso Mancini Griffoli, Christoph Meyer, Jean-Marc Natal and Attilio Zanetti: Determinants of the Swiss Franc Real Exchange Rate.

2014-7 Konrad Adler and Christian Grisse: Real exchange rates and fundamentals: robustness across alternative model specifications.

2014-6 Matthias Gubler: Carry Trade Activities: A Multivariate Threshold Model Analysis.

2014-5 Raphael A. Auer and Aaron Mehrotra: Trade linkages and the globalisation of inflation in Asia and the Pacific.

2014-4 Cyril Monnet and Thomas Nellen: The Collateral Costs of Clearing.

2014-3 Filippo Brutti and Philip Sauré: Repatriation of Debt in the Euro Crisis: Evidence for the Secondary Market Theory.

2014-2 Simone Auer: Monetary Policy Shocks and Foreign Investment Income: Evidence from a large Bayesian VAR.

2014-1 Thomas Nitschka: The Good? The Bad? The Ugly? Which news drive (co)variation in Swiss and US bond and stock excess returns?

From 2015, this publication series will be renamed SNB Working Papers.

All SNB Working Papers are available for download at: www.snb.ch, Research

Subscriptions or individual issues can be ordered at: Swiss National Bank

Library

P.O. Box

$\mathrm{CH}-8022$ Zurich

Phone: +41446313284

Fax: +41446318114

E-mail: library@snb.ch 
